\title{
A LEI DE ANISTIA BRASILEIRA: OS CRIMES CONEXOS, A DUPLA VIA E TRATADOS DE DIREITOS HUMANOS
}

THE BRAZILIAN AMNESTY LAW: THE CONNECTION OF CRIMES, THE DOUBLE FACE AND THE HUMAN RIGHT'S TREATIES

Lucia Elena Arantes Ferreira Bastos*

\begin{abstract}
Resumo:
Tendo como pressuposto o Direito Internacional, o que será discutido no presente artigo é a relação entre a soberania e o respeito aos tratados de proteção dos Direitos Humanos, quando se trata da aplicação das leis de anistias aos crimes internacionais. Para tanto, será observado o tratamento dispensado às distintas anistias no Brasil, em especial a de 1979. A esse tema principal agregam-se assuntos correlatos como a incorporação das normas de proteção dos Direitos Humanos, a coexistência dos Estados diante do Direito Internacional, a ditadura, a prática do terror de Estado, as regras aplicáveis durante um período de tensão interna e um conflito armado ou guerra civil e a possibilidade do perdão às violações cometidas em determinados períodos históricos.

Palavras-Chave: Direito Internacional. Direito Internacional Humanitário. Direitos Humanos. Anistia. Ditadura. Violações. Crimes internacionais. Crimes contra a humanidade.
\end{abstract}

\begin{abstract}
:
Considering the context of the international law, what is discussed in this article is the relationship between the sovereignty and the compliance with the treaties of Human Rights protection, and more specifically the treaties that regard the enforcement amnesties laws to international crimes. Therefore, it is studied several amnesties in Brazil, emphasizing the one of 1979. In addition, this study comprises correlated subjects; such as the incorporation of norms of Human Rights protection; the coexistence of States and the International Law, the dictatorship, the practice of the terror, the applicability of rules not only in internal tension but also in armed conflict or civil war and the possibility of the forgiveness to violations committed in certain historical periods.
\end{abstract}

Keywords: International Law. Humanitarian International Law. Human Rights. Amnesty. Dictatorship. Violations. International crimes. Crimes against the humanity.

1. Introdução

O artigo visa analisar a Lei de Anistia brasileira, de 1979, a partir dos seguintes temas: (i) a sua extensão, que compreende o entendimento sobre os crimes

\footnotetext{
Doutora em Direito Internacional pela Faculdade de Direito da Universidade de São Paulo. Pesquisadora do Núcleo de Estudos da Violência da Universidade de São Paulo (NEV-USP), onde cursa o Pós-doutorado, bolsista pela Fapesp.
} 
conexos e os crimes políticos; (ii) o rol dos beneficiados, que inclui tanto os agentes estatais quanto os adversários políticos do regime (a "dupla via"), e (iii) a sua validade, ou seja, quando surge conflito com os tratados que versam sobre os Direitos Humanos.

Para tanto, promove-se uma reflexão sobre: (i) o tratamento dispensado à anistia em casos brasileiros anteriores a 1979; (ii) o contexto no qual se elaborou a referida lei; (iii) a discussão sobre a aplicação da anistia à uma tensão interna versus um conflito armado, ambos observados de acordo com o Direito Internacional humanitário, e (iv) a solução possível para um conflito entre uma norma interna e uma disposição internacional oriunda de um tratado.

A partir do final dos anos 70 e início dos 80 muitas ditaduras ${ }^{1}$ foram sendo substituídas por democracias em diferentes regiões do planeta, e estes Estados em transição depararam-se com um dilema: deveriam ou não responsabilizar os regimes antecedentes pelas violações dos Direitos Humanos? Essa responsabilização poderia colocar em risco a transferência de poder?

O que é possível observar nesses casos, ainda que distintos entre si, é que o objetivo da transição política entrava em conflito com o propósito de punir os crimes cometidos no passado, porque o raciocínio difundido era que, de um lado, os antigos ditadores dificilmente deixariam os seus postos, se tivessem receio de que poderia haver uma investigação pelos seus atos, e, por outro lado, grupos nacionais e a sociedade internacional tinham razões para demandar uma resignação e punição desses ditadores. Em muitos casos, o resultado foi a aplicação da lei de anistia, vista como uma forma para tentar solucionar esse dilema.

À primeira vista, uma lei de anistia parece oferecer um atrativo rápido e eficiente em um período de transição, pois facilita uma rendição de poder - não-violenta por parte dos ditadores, e evita, assim, o recurso à intervenção armada, tanto nacional quanto internacional. Entretanto, sob o ponto de vista do Direito Internacional, a lei de anistia, em geral, apresenta problemas quanto a sua fundamentação. Primeiro, porque ela é normalmente emitida para servir e proteger o próprio ditador e seus subordinados. Segundo, ela pode conflitar com os padrões legais constitucionais do Estado. Terceiro, ela, geralmente, viola as obrigações internacionais do Estado de processar certos crimes e de oferecer aos seus cidadãos direitos específicos e indenização pelos atos ilícitos cometidos.

E o que se observa hoje é que, enquanto muitos consideravam a anistia como um fenômeno ultrapassado e esquecido nos anos 80, ela recentemente tomou uma importância renovada. A tendência, em relação ao crescimento dos processos iniciados sob

$\overline{1}$ O termo ditadura é aqui utilizado na acepção apresentada a seguir no item 3 do artigo. 
o princípio da jurisdição universal, sugere que nos próximos anos vários Estados deverão determinar se reconhecem ou-não validade da norma internacional. Além do que, como a comunidade internacional tem se tornado mais engajada no processo de reconciliação pósconflito, a anistia ressurgiu como um importante instrumento político e legal. ${ }^{2}$

O problema central, sob a visão do Direito Internacional, é que, em muitos casos, ao oferecer a anistia, os Estados cederam garantias fundamentais dos cidadãos que são asseguradas por tratados internacionais e legislações domésticas. Além do que, considera-se que as anistias, normalmente, são concedidas em períodos de grande instabilidade social ou ao final de tempos de guerra com o propósito de recuperar as tropas e forçar a paz e a reconciliação. No entanto, mais recentemente e de forma mais controversa, as anistias foram usadas para proteger indivíduos da responsabilidade por algumas das piores atrocidades cometidas na História da Humanidade.

O que torna o uso da anistia hoje tão problemática não é somente a falta de responsabilização daqueles indivíduos que cometeram violações sistemáticas dos Direitos Humanos, mas, sim, o seu uso crescente e a sua aceitação em um mundo que acatou globalmente a idéia de que existem Direitos Humanos que são universais, ${ }^{3}$ para os quais nenhuma derrogação é permitida, em particular o direito absoluto contra a tortura, a escravidão, o genocídio e outras graves violações dos Direitos Humanos.

Historicamente, anistias para crimes de guerra e para o que hoje se conhece como crimes contra a humanidade não eram comuns, precisamente porque existia pouca aceitação da noção de que os oficiais dos Estados poderiam ser responsabilizados por tais atos $^{4}$. Não é que a anistia está agora sendo utilizada em áreas antes desconhecidas, ou de maneira nova e distinta, mas, sim, que surgiu um consenso nos últimos 60 anos de que certos atos cometidos pelos agentes estatais não estão mais isentos de responsabilidade 5 .

2 BURKE-WHITE, William W. Reframing impunity: applying liberal international law theory to an analysis of amnesty legislation. Harvard International Law Journal, v. 42, n. 2, p. 467-533, 2001.

3 A respeito da universalidade dos Direitos Humanos, compreende-se que ela está vinculada ao próprio fato do "ser humano", que por ser o mesmo em qualquer lugar do mundo; leva à interpretação de que as mesmas regras deveriam valer para todos os homens em todas as épocas e locais. A Declaração de 1948 procede à afirmação universal de que nenhuma lei nacional pode retirar do homem o "direito de ser humano" e alarga a toda a comunidade mundial o campo de exercício dos Direitos Humanos. No entanto, não se pode ignorar que esse conceito de universalidade dos Direitos Humanos não é admitido em todos os lugares e que os Direitos Humanos ainda não alcançaram a universalidade pretendida. Ver: CABRILLAC, Rémy; FRISON-ROCHE, Marie-Anne e; REVET, Thierry (Orgs.). Libertés et droits fondamentaux. 12. ed.; Paris: Dalloz, 2006. p. 33.

4 Essa mudança de perspectiva deu-se a partir dos Tribunais de Nuremberg e de Tóquio, constituídos para julgar os crimes cometidos durante a II Guerra Mundial. Esses tribunais simbolizaram a resposta para o horror do genocídio praticado pelos nazistas na Europa e para os crimes cometidos pelos japoneses durante a ocupação do sudeste da Ásia. Havia a convicção disseminada de que nunca mais uma tirania poderia desconsiderar a dignidade humana e continuar impune. Ver: CASSESE, Antonio. International criminal law. New York: Oxford University Press, 2003. p. 329-330.

5 Existe um interesse universal na repressão desses crimes. Nos casos de crimes internacionais, os acusados devem ser processados e punidos por qualquer Estado, sem que haja a exigência de um vínculo territorial ou 


\section{Histórico sobre anistias anteriores}

Desde o Código Penal, de 1890, a anistia figurava dentre as conseqüências próprias de extinção tanto da ação quanto da pena, ${ }^{6}$ e essa tradição foi mantida no atual Código Penal, que foi promulgado em 1940. As Constituições anteriores a de 1988 também mantinham o direito de graça, com pequenas modificações, que não alteravam, entretanto, o conteúdo nem a prática da anistia, ${ }^{7}$ seguindo-se o espírito de conciliação e as finalidades que assinalavam a sua existência no Direito brasileiro.

Por exemplo, logo após a Revolução de $1930,{ }^{8}$ foi promulgada uma anistia que compreendia tanto os crimes políticos quanto militares. ${ }^{9}$ Em 1931, uma nova lei de anistia excluiu do rol dos benefícios os delitos comuns e os meramente funcionais. ${ }^{10} \mathrm{Em}$ abril de 1945, anunciadas as eleições gerais, o governo concedeu anistia aos que tivessem cometido crimes políticos desde 16 de julho de 1934, data da Constituição anulada pelo golpe de Estado de 1937. ${ }^{11}$ Em setembro de 1945, nova anistia era emitida para acusados

de nacionalidade com o perpetrador ou com a vítima. E, se o perpetrador atuou na sua capacidade oficial de fato ou de direito, o Estado para o qual ele atuou cometeu um ato ilegal, tornando-se impedida, portanto, a concessão de imunidade tanto no âmbito civil quanto penal.

6 O Código Penal brasileiro considerou a anistia como uma causa extintiva da punibilidade (art. 107, inc. II), isso significa que ela pode ser concedida a qualquer tempo. A diferença é que, se ela for oferecida: (i) antes da ação, tem a faculdade de impedir que esta se instale, (ii) no transcurso do processo e antes da condenação, cancela o processo, extinguindo todos os efeitos penais (atinge-se o jus puniendi do Estado), e, (iii) depois da condenação, evita ou encerra o cumprimento da pena imposta (extinguindo a pretensão executória do Estado).

7 CARVAlHO FILHO, Aloysio. Comentários ao código penal. Rio de Janeiro: Forense, 1958. v. 4, p. 103161.

8 No contexto histórico, a articulação revolucionária, iniciada em Minas Gerais e no Rio Grande do Sul, em 3 de outubro de 1930, contou com setores importantes do exército, sob o comando do tenente-coronel Góis Monteiro. O movimento incorporou militares rebeldes da década de 1920, e tenentes, apesar dos conflitos internos com militares de alta patente. O governo de Washington Luís pouco resistiu aos revolucionários. A velocidade com que os diversos estados da União foram sendo dominados demonstrava a fraqueza do regime. Ver: FAUSTO, Boris. A revolução de 1930. In: MOTA, Carlos Guilherme (Org.). Brasil em perspectiva. São Paulo; Difel, 1981.

9 O Decreto n. 19.395 de 8 de novembro de 1930, concedia anistia a todos os civis e militares envolvidos nos movimentos revolucionários ocorridos no país: “Art. 1 É concedida anistia a todos os civis e militares que direta ou indiretamente se envolveram nos movimentos revolucionários, ocorridos no país; $§ 1$ São incluídos nesta anistia todos os crimes políticos e militares ou conexos como esse; § 2 Ficam em perpétuo silêncio, como se nunca tivessem existido, os processos e sentenças relativos a esses mesmos fatos e aos delitos políticos de imprensa".

${ }^{10}$ Por meio do Decreto-Lei n. 20.558, de 24 de outubro de 1931, Getúlio Vargas declarou "anistiados os elementos civis, direta ou indiretamente implicados em movimentos sediciosos de qualquer natureza". Dessa forma, todos os políticos do Partido Republicano Mineiro enquadrados no "Movimento de 18 de agosto" (uma tentativa de deposição do governador mineiro Olegário Maciel) ficaram livres dos processos que contra eles propunha o governo de Minas Gerais. Quanto aos oficiais e praças, que também tinham se envolvido, somente foram beneficiados seis dias após, por meio do Decreto n. 10.119, de 30 de outubro de 1931.

11 Trata-se do Decreto-Lei n. 7474, de 18 de abril de 1945, com que se beneficiaram os comunistas, inclusive Luís Carlos Prestes, graças a isso eleito senador pelo Distrito Federal à Constituinte Nacional de 1946. Dispunha o referido Decreto-lei: “Art. 1 É concedida anistia a todos quantos tenham cometido crimes políticos desde 16 
por crimes de injúria aos poderes públicos e também para os responsáveis por crimes de qualquer natureza, considerados políticos ou-não, ocorridos durante ou logo após a realização de comícios, passeatas ou outras manifestações políticas. ${ }^{12}$

O Decreto legislativo n. 18 de 1951 anistiava trabalhadores que haviam sido dispensados por terem participado de movimentos grevistas; o que gerou interpretações distintas pela própria Justiça do Trabalho, que, em determinados momentos, admitiu aplicação irrestrita da anistia, determinando a reintegração no emprego, assegurando, inclusive, os salários atrasados desde a data do afastamento, e em outras ocasiões, questionou a medida, sob a alegação da sua incompatibilidade com as faltas trabalhistas. Ao final, o Supremo Tribunal Federal adotou esse último critério, segundo o qual a anistia, pelo fato de ser um instituto de âmbito penal, só produz efeitos penais, não podendo, portanto, influenciar na esfera de interesses privados. ${ }^{13}$

\section{O conceito de ditadura e a doutrina militar}

Para se ter a exata compreensão do contexto histórico em que ocorreu a concessão da lei de anistia de 1979, no Brasil, importa conhecer o regime político no qual a lei se inseria: a ditadura. O termo ditadura origina-se na dictatura romana. Entretanto, o significado atual da palavra é bastante distinto da instituição a que se aplicava na Roma republicana. $^{14}$

A ditadura romana compunha-se de um órgão extraordinário, ativado por processos e limites definidos, para que se enfrentasse uma situação de emergência. De tal forma que a razão para a qual se nomeava um ditador era claramente estipulada, e o ditador a ela deveria se restringir. Normalmente, a ditadura era aplicada na condução de uma guerra ou na solução de uma crise interna.

$\mathrm{Na}$ atualidade, a palavra ditadura tende a abarcar todos os regimes antidemocráticos ou não-democráticos. A semelhança entre as ditaduras romana e a atual é a concentração e o caráter absoluto do poder. E, diferentemente da ditadura romana, a

de julho de 1934 até a data da publicação deste decreto-lei. § 1 Não se compreendem nesta anistia os crimes comuns não conexos com os políticos, nem os praticados, em tempo de guerra, contra a segurança do Estado e definidos no Decreto-lei n. 4.766, de 1 de outubro de 1942. § 2 Consideram-se conexos para os efeitos deste artigo os crimes comuns praticados com fins políticos e que tenham sido julgados, pelo Tribunal de Segurança Nacional".

12 Era o Decreto n. 7.943, de 10 de setembro de 1945, que limitava a anistia, por isso mesmo, aos fatos ocorridos até a data em que se permitira a arregimentação partidária, com a promulgação da nova lei eleitoral, isto é, 28 de maio daquele ano.

${ }^{13}$ CARVAlHO FILHO, Aloysio. Comentários ao código penal. Rio de Janeiro: Forense, 1958. v. 4, p. 103161.

${ }^{14}$ STOPPINO, Mário. Ditadura. In: BOBBIO, Norberto; MATTEUCCI, Nicola; PASQUINO, Gianfranco (Orgs.). Dicionário de política. 3. ed. Brasília: UnB, 1991. 
moderna não é autorizada por regras constitucionais: surge de fato ou vem a subverter uma ordem política preexistente. E, apesar da afirmação de muitas ditaduras modernas de que são temporárias, sua duração não está necessariamente fixada e sua manutenção passa a depender dos acontecimentos históricos.

Normalmente, a ditadura retrata uma ruptura da tradição, pois ela se instala utilizando a mobilização política de uma parte da sociedade, no mesmo momento em que subjuga com violência uma outra parte. E a ditadura não pode assegurar a sua continuidade, de modo regular, nem mesmo por meio do processo democrático, de que é a negação, ou pelo princípio hereditário, que se contrapõe com a sua pretensão de representar os interesses do povo.

Por isso, cabe aqui também a análise do problema da legitimação do poder de um regime ditatorial. Sob o aspecto da legitimidade, a ditadura é marcada por uma contradição em relação ao regime democrático, já que concentra o poder e o transmite rigidamente do alto para baixo. É natural que uma ditadura tenda a se apresentar como expressão legítima dos interesses do povo, por isso se utilizam de todos os artifícios para comprovar que possuem a anuência do povo, tal como os plebiscitos e os encontros de massa nos quais o chefe entra em contato direto com seus representantes.

Assim, a ditadura representa uma espécie de democracia subvertida, ${ }^{15}$ na qual o povo é forçado a manifestar uma total adesão à orientação política do ditador, a fim de que este último possa divulgar que sua ação se encontra estruturada na vontade popular. No entanto, todos esses artifícios não conferem à ditadura a legitimidade democrática, porque não podem eliminar o fato de a autoridade política ter sido transmitida do alto para baixo, e não vice-versa, como se espera em um espaço democrático.

Por fim, a designação "ditadura militar" advém da classificação das ditaduras de acordo com as características da elite dominante. Nesse caso, os critérios de classificação adotados são o tipo de origem ou de recrutamento do pessoal político de cúpula e a distribuição interna do poder. Por meio desse critério, distingue-se entre: (i) as "ditaduras militares", nas quais o pessoal de cúpula é recrutado nas fileiras do exército, e (ii) as "ditaduras políticas", quando essa cúpula pertence a uma facção da classe política ou de um partido político que após a chegada ao poder transforma-se em partido único.

No caso brasileiro, em que se constituiu uma ditadura militar a partir do golpe de 1964, importa lembrar também a justificativa para essa tomada de poder, a qual se encontrava na doutrina militar reinante na época, segundo a qual, desde o final da II Guerra Mundial, existiriam três tipos de conflitos para os quais se delineavam três tipos de

${ }^{15}$ STOPPINO, Mário. Ditadura. In: BOBBIO, Norberto; MATTEUCCI, Nicola; PASQUINO, Gianfranco (Orgs.). Dicionário de política. 3. ed. Brasília: UnB, 1991. 
missão. ${ }^{16}$ Em primeiro plano encontrava-se a possibilidade de uma confrontação entre as grandes potências; neste caso, se ela fosse nuclear, restaria muito pouco para os militares brasileiros fazerem. Se o confronto tivesse traços convencionais no âmbito da Europa, por exemplo, os militares da América do Sul, que se alinhavam aos Estados Unidos, também pouco teriam a fazer.

A segunda previsão relacionava-se aos conflitos regionais na América do Sul. Nesse tipo de missão, os militares brasileiros poderiam ter uma tarefa mais definida: proteger o território nacional contra as ameaças à sua integridade. Porém, ainda que essa missão existisse no aspecto doutrinário, no caso concreto também o Brasil teria pouco a desempenhar, pois a posição hegemônica dos Estados Unidos e o quase-monopólio que eles possuíam no fornecimento de armas, doutrinas e treinamento para as Forças Armadas dos países latino-americanos, em tese, restringiriam a ocorrência de um conflito regional relevante. ${ }^{17}$

Assim, o terceiro tipo de missão foi o que mais predominou no continente e no Brasil ao longo das décadas de 60, 70 e 80: a segurança interna. Nessa previsão, a hipótese era de que os inimigos do país estavam no próprio território, atuando como nacionais a serviço de potência estrangeira ou como estrangeiros a serviço de países inimigos. De acordo com essa doutrina, caberia aos militares combater os inimigos internos, combate esse que levou a uma série de implicações negativas em relação à proteção dos Direitos Humanos e da cidadania a partir da adoção não apenas do regime ditatorial como da manutenção de um estado de exceção.

A afirmação de que naquele período de 1964-1985 viveu-se um estado de exceção no Brasil leva naturalmente à necessidade de compreensão do conceito do estado de exceção. Definição essa que, para Agamben, ${ }^{18}$ é muito difícil de se fazer já que, na maioria das vezes, o que se faz é considerar o problema como uma questão de fato e não como um verdadeiro problema jurídico.

\footnotetext{
${ }^{16}$ BARROS, Alexandre. Problemas de transição democrática na frente militar: a definição do papel dos militares, a mudança da doutrina e a modernização do país. Política e Estratégia, v. 6, n. 2, p. 206-214, 1998.

17 Nas palavras de Alexandre Barros: “(...)Para sermos mais claros, a possibilidade de guerra inexistia. $\mathrm{O}$ treinamento que os oficiais brasileiros (e latino-americanos) recebiam desestimulava que eles pensassem em entrar em conflito com seus vizinhos no continente. Se não bastasse isso, se houvesse a idéia, não existiriam os meios. Os Estados Unidos, que eram o poder mais interessado na estabilidade do continente, dispunham, em bases praticamente monopolistas, dos meios de fazer a guerra. Eles eram, praticamente, os únicos supridores de material bélico para os países das Américas do Sul e Central”. Ver: BARROS, Alexandre. op. cit., p. 206-214. E Rouquié também partilha dessa mesma idéia: "Foi a partir do final da década de sessenta, e sobretudo depois de 1973, que se impuseram novas interpretações que relacionavam a militarização com a ação de interesses externos às sociedades latino-americanas, (...) Por um lado, partia-se enfim de dados reais: a extroversão econômica e a dominação dos países industrializados, sobretudo dos Estados Unidos, a dependência cumulativa e, muito particularmente, sua ação na formação e no funcionamento das instituições armadas". Ver: ROUQUIÉ, Alain. O estado militar na América Latina. São Paulo: Alfa-Omega, 1984. p. XIX.

18 AGAMBEN, Giorgio. Estado de exceção. São Paulo: Boitempo, 2004. p. 11-13.
} 
Essa dificuldade dá-se porque o estado de exceção encontra-se em um ponto de desequilíbrio entre Direito Público e fato político, pois é preciso compreender se esse desequilíbrio é fruto de um período de crise política e, como tal, deve ser analisado no âmbito político e não no jurídico-constitucional, ou se as medidas excepcionais inserem-se no contexto paradoxal de medidas jurídicas que não podem ser compreendidas no plano do Direito.

A forte vinculação do estado de exceção com a guerra civil, a insurreição e a resistência torna ainda mais difícil a sua definição, pois, visto que se trata do oposto do estado de normalidade, a guerra civil ou a resistência localizam-se em uma zona de indecisão, e, nestes casos, o estado de exceção torna-se uma resposta imediata do poder estatal ao extremismo dos conflitos internos. O que se observa, porém, é o perigo de se decretar tais estados de exceção de forma continuada e ilimitada, pois, no decorrer do século XX (principalmente a partir do Terceiro Reich ${ }^{19}$ ) e ainda hoje, tem-se assistido à criação voluntária de estados de exceção permanentes (ainda que não-declarados no sentido técnico), como se fosse uma das práticas essenciais dos Estados contemporâneos, mesmo dos chamados Estados democráticos. O que acaba levando o estado de exceção a apresentar-se em um padrão de indeterminação entre democracia e absolutismo, pois se configura em uma contínua erosão do Poder Legislativo, o qual muitas vezes restringe-se a ratificar disposições promulgadas pelo Poder Executivo sob a forma de decretos com força de lei.

O estado de exceção representaria, então, um espaço vazio de direito, uma zona de anomia em que todas as formulações jurídicas estão desativadas. Na visão de Agamben seriam, portanto, falsas as doutrinas que tentam vincular o estado de exceção ao direito, ou a doutrina que vê no estado de exceção o exercício de um direito do Estado à própria defesa ou a restauração de uma situação anterior: “(...) O estado de necessidade não é um "estado do direito", mas um espaço sem direito (mesmo não sendo um estado de natureza, mas se apresenta como a anomia que resulta da suspensão do direito)" ${ }^{20}$

\footnotetext{
${ }^{19}$ Nas palavras de Agamben: “(...) Logo que tomou o poder (...) Hitler promulgou, no dia 28 de fevereiro, o Decreto para a proteção do povo e do Estado, que suspendia os artigos da Constituição de Weimar relativos às liberdades individuais. O decreto nunca foi revogado, de modo que todo o Terceiro Reich pode ser considerado, do ponto do vista jurídico, como um estado de exceção que durou 12 anos. O totalitarismo moderno pode ser definido, nesse sentido, como a instauração, por meio do estado de exceção, de uma guerra civil legal que permite a eliminação física não só dos adversários políticos, mas também de categorias inteiras de cidadãos que, por qualquer razão, pareçam não integráveis ao sistema político". Ver: AGAMBEN, Giorgio. op. cit., p. 12-13.

${ }^{20}$ AGAMBEN, Giorgio. op. cit., p. 80.
} 
A anistia brasileira, objeto do presente estudo, concedida pela Lei n. 6.683, de 28 de agosto de 1979, era decorrência de uma reivindicação antiga, que remontava desde o momento do golpe militar de 1964, quando da edição do Ato Institucional n. 1, o qual havia estabelecido o estado de exceção no País, ocasionando a cassação dos mandatos eletivos e dos direitos civis de centenas de pessoas. Como decorrência lógica, os valores liberais e democráticos reinantes na época foram relativizados com as seqüências de intimidações, prisões e a censura à Imprensa, o que levou as organizações da chamada esquerda revolucionária a pegar em armas. Até que, em 1968, como forma de contenção aos crescentes descontentamentos, o Governo editou o Ato Institucional n. 5, decretou o fechamento do Congresso, e, aos poucos, os revolucionários foram sendo capturados, mortos ou banidos, ao mesmo tempo em que a tortura passava a ser sistematicamente utilizada contra os prisioneiros políticos.

A maior parte da população não atuou de forma direta nos movimentos contrários ao regime. ${ }^{21}$ No início parecia, inclusive, não compreendê-lo, e na opinião de Gaspari e Mezarobba ${ }^{22}$ essa apatia estava relacionada com uma espécie de controle imposto pela força do terror, que era aplicado pelo regime militar. Terror, aliás, que na época havia sido alvo de denúncias tanto na Europa quanto nos Estados Unidos. ${ }^{23}$

Mas, ao mesmo tempo em que o Governo seguia desmentindo as críticas de que no Brasil a tortura era uma política de Estado, sem se preocupar com a pressão internacional, a mobilização social local pela anistia começava a adquirir um caráter mais amplo, pois a prisão nas condições de um regime militar representava muito mais do que a privação da liberdade; simbolizava, na verdade, uma ameaça à integridade física, um risco de morte iminente que, aos poucos, foi se tornando patente à sociedade. Então, durante o regime militar brasileiro, o esforço em prol da anistia esteve sempre associado à luta pela retomada da democracia, pela volta do Estado de Direito e pelo reconhecimento

\footnotetext{
${ }^{21}$ Nas palavras de Gaspari: “A sociedade poderia não estar interessada em sustentar a ditadura militar, mas interessava-se muito menos pela chegada à ditadura do proletariado ou de qualquer grupo político ou social que se auto-intitulasse sua vanguarda. A natureza intrinsecamente revolucionária das organizações armadas retirou-lhes o apoio, ainda que tênue, do grosso das forças que se opunham ao regime. Elas viam na estrutura da Igreja católica e na militância oposicionista de civis como Tancredo Neves e Ulysses Guimarães um estorvo no caminho da revolução. Eles, por seu lado, viam na luta armada um estorvo para a redemocratização". Ver: GASPARI, Elio. A ditadura escancarada. São Paulo: Companhia das Letras, 2002. p. 194.

${ }^{22}$ Elio Gaspari menciona que: "A classe média, assustada pelas pancadarias, não entendia mais o governo que ajudara a entronizar...”. Ver: GASPARI, Elio. op. cit., p. 233 e MEZAROBBA, Glenda. Um acerto de contas com o futuro: a anistia e suas conseqüências - um estudo do caso brasileiro. 2003. Dissertação (Mestrado) - Faculdade de Filosofia, Letras e Ciências Humanas, Universidade de São Paulo, São Paulo. p. 14.

${ }^{23}$ GASPARI, Elio. A ditadura escancarada. São Paulo: Companhia das Letras, 2002. p. 280-297.
} 
e respeito aos Direitos Humanos. ${ }^{24}$ A transição para a democracia não foi um processo revolucionário radical. Ao contrário, foi um período de mudança política dos mais suaves que se tem notícia na história. ${ }^{25}$ As Forças Armadas continuaram a existir depois do dia 15 de março de 1985, exatamente da mesma forma como eram constituídas antes; os mesmos oficiais que eram parte dos quadros militares antes de 15 de março neles permaneceram e não existiram expurgos.

Foi exatamente nesse período de transição sem grandes rupturas que se adotou a lei de anistia brasileira. No dia 27 de junho de 1979, o então presidente João Baptista Figueiredo assinou o projeto de anistia e o enviou para o Congresso Nacional. Em sua mensagem, o presidente Figueiredo afirmou que se tratava de um momento propício à pacificação e que a anistia requisitava, para cumprir a sua função política, de um desarmamento dos espíritos, a fim de que fosse alcançada a coexistência democrática. ${ }^{26}$

Anos mais tarde, porém, Fábio Konder $\mathrm{Comparato}^{27}$ questionou esse posicionamento pacificador do Governo:

É politicamente indefensável, com efeito, pretender que os que governavam acima das leis, sob a vigência do chamado Ato Institucional n. 5, possam legitimamente obter de um legislador submisso a anistia para os crimes que cometeram no exercício de suas funções. Que democracia é essa que se inaugura no achincalhe? A pretensa "pacificação dos espíritos", de resto, foi sempre uma farsa grosseira, pois à época da anistia não havia o menor vislumbre de oposição armada ao regime. Tudo se passou como se um ditador corrupto qualquer, desejando abandonar o poder sem riscos, negociasse com o sucessor uma pré-anistia para os seus desmandos.

5. A legitimidade e o escopo da lei de anistia brasileira

A Lei de Anistia brasileira encontrava o seu fundamento no art. 57, inc. VI, combinado com o art. 51, § 2 da Constituição Federal, de 1969. Como o projeto foi apresentado por um governo militar, no qual as eleições para a Presidência da República

\footnotetext{
${ }^{24}$ Prova disso encontra-se na manifestação do jurista Goffredo Telles Júnior, em agosto de 1977, em sua "Carta aos Brasileiros", lida no pátio da Faculdade de Direito, no Largo São Francisco, em São Paulo; e ainda no ano de 1977 a ocorrência de manifestações estudantis em protesto contra as prisões e a tortura de presos políticos.

${ }^{25}$ BARROS, Alexandre. Problemas de transição democrática na frente militar: a definição do papel dos militares, a mudança da doutrina e a modernização do país. Política e Estratégia, v. 6, n. 2, p. 206-214, p. 206-214.

${ }^{26}$ MEZAROBBA, Glenda. op. cit.

${ }^{27}$ COMPARATO, Fábio Konder. Questão de decência. Folha de São Paulo, 10 de setembro de 1995, Caderno Tendências e Debates, p. 1-3.
} 
eram indiretas e o Congresso Nacional era composto também por senadores "biônicos", 28 na anistia brasileira encontrava-se, portanto, ausente o elemento da legitimidade nacional, entendida esta como a representação da vontade popular em um Governo eleito pelos seus próprios cidadãos.

A falta de legitimidade do projeto de lei de anistia brasileira, no sentido de não se adequar aos anseios do povo, pôde ser atestada, por exemplo, a partir do momento em que as emendas começaram a ser apresentadas. No total foram oferecidas 305 emendas de 134 parlamentares (26 senadores e 108 deputados). Dentre as várias propostas de alterações encontravam-se: (i) a exclusão dos benefícios da anistia, por serem crimes comuns os atos de sevícia ou de tortura; (ii) a inclusão no rol de anistiados os indivíduos que já haviam sido condenados pela prática de terrorismo, assalto, seqüestro e atentado pessoal; (iii) a retirada do benefício da graça àqueles que tivessem ordenado, ou realizado, prisões sem observar as formalidades legais ou de forma abusiva. ${ }^{29}$

No que diz respeito ao escopo da lei, no texto inicialmente proposto pelo Governo militar, havia a previsão no art. 1 sobre a concessão de anistia a todos que, no período compreendido entre 2 de setembro de 1961 e 31 de dezembro de 1978, tivessem cometido: (i) crimes políticos ou conexos a estes, cujos direitos políticos haviam sido suspensos, (ii) aos servidores da administração pública direta e indireta, de fundações vinculadas ao Poder Público, (iii) aos servidores dos Poderes Legislativo e Judiciário e

\footnotetext{
${ }^{28}$ Nas eleições parlamentares de novembro de 1974, o MDB venceu nos grandes centros urbanos, elegendo um grande número de deputados e vários senadores. Esse resultado demonstrava o crescente descontentamento da população em relação ao regime ditatorial. Para manter o ritmo do processo sob controle, o governo adotou medidas especiais para as eleições municipais de 1976, baixando a chamada "Lei Falcão" (nome do Ministro da Justiça) em junho, que limitava a propaganda eleitoral à foto e a um currículo sumário. Frente aos crescentes obstáculos que o Congresso punha aos projetos do Governo e prevendo uma vitória da oposição nas eleições de 1978, o então Presidente Geisel fechou o Congresso Nacional por duas semanas em abril de 1977, alterou as regras eleitorais, criando o senador "biônico", ou seja, um em cada três senadores passou a ser eleito indiretamente pelas assembléias legislativas de seus Estados, e mantendo eleições indiretas para governador. Nas eleições de 1978, a oposição fez mais votos e aumentou sua bancada, mas permaneceu em minoria devido ao mecanismo dos "biônicos" e ao distorcido coeficiente de representação que sobrerepresentava eleitoralmente os pouco povoados Estados do norte e nordeste que dependiam do governo federal. Ver: VIZENTINI, Paulo Gilberto Fagundes. A experiência histórica do Brasil e da Argentina contemporâneos: autoritarismo e desenvolvimento (1964-1985). In: LLADÓS, José Maria; GUIMARÃES, Samuel Pinheiro (Orgs.). Perspectivas: Brasil e Argentina. Brasília: IPRI, 2000. p. 435-485.

${ }^{29}$ Sobre essa afirmação, Mezarobba comentou: "Houve quem se preocupasse em evitar que os violadores de Direitos Humanos acabassem por se beneficiar da lei. Foi o caso do senador Humberto Lucena (MDB-PB) e da seção da OAB em São Paulo, que sugeriu a parlamentares emenda nesse sentido. O deputado Pacheco Chaves (MDB-SP) justificou a iniciativa: "O projeto está, cabe ressaltar, eivado de grave contradição: anistiam-se o homicídio, o constrangimento ilegal, em suma a violência cometida em nome do Estado e praticada nos gabinetes de tortura, sob o manto da impunidade garantida pelo regime de exceção, porém, anistiados não são os que, de modo tresloucado, recorreram à violência na luta contra o regime, mas sempre com risco pessoal". Para ele, ou se excluíam os torturadores, afastando-se o crime conexo do elenco dos anistiados, ou se estendia a anistia a todos, sem restrições, com a supressão do art. 1, § 2". Vide: MEZAROBBA, Glenda. op. cit., p. 36.
} 
(iv) aos militares, dirigentes e representantes sindicais, punidos com fundamento em Atos Institucionais e complementares.

No entanto, restariam excluídos dos benefícios da anistia, de acordo com o art. $1, \S 2$, aqueles que já haviam sido condenados pela prática de crimes de terrorismo, assalto, seqüestro e atentado pessoal que se constituíam em crimes políticos de resistência ao regime estabelecido.

Na época, a exclusão dos condenados causou polêmica na análise do projeto diante do Congresso Nacional, tanto que o senador Teotônio Vilela, eleito presidente da comissão mista para analisar o projeto do Governo, criticou essa posição:

O projeto (...) Beneficiou alguns para deixar de fora os condenados formalmente. Dois acusados pelo mesmo fato terão tratamento diametralmente oposto. O condenado seguirá na prisão. O que ainda não foi sentenciado recuperará os seus direitos e não responderá pelos atos praticados. Não há argumento lógico, nem princípio ético que justifique tão odiosa desigualdade. ${ }^{30}$

E a mesma indignação surgiu entre os juristas, como Nilo Batista, ${ }^{31}$ ao mencionar que: “(...) há injustiça material quando co-réus do mesmo fato se encontrem em situações tão díspares: um, anistiado; o outro, condenado definitivamente".

Ainda sobre a questão do propósito da anistia, no caso brasileiro, foi possível observar que se tratava de uma proposta a mais abrangente possível, pois sob o conceito de "crime conexo" seria possível abarcar inúmeras violações dos Direitos Humanos. E, apesar das reflexões de vários parlamentares sobre temas vinculados à questão dos desaparecidos políticos, sugerindo emendas para: (i) a inclusão do pagamento de pensão a dependentes de pessoas que sumiram após terem sido detidas por órgãos de segurança; (ii) a abertura de sindicâncias, pelo Ministério da Justiça, para apurar os desaparecimentos; (iii) a instauração de inquérito pela Polícia Federal para identificar as circunstâncias dos desaparecimentos; e (iv) a equiparação do desaparecimento à morte natural, o Governo parecia não se importar com as falhas apontadas em seu projeto.

Ao final das discussões, que foram travadas no Congresso, o relator do projeto rejeitou os substitutivos e as emendas apresentadas, e, na maioria dos casos, a justificativa foi de que se tratava de propostas "impertinentes". ${ }^{32}$ Ainda assim, o relator apresentou um substitutivo ao projeto do Governo, que acrescentou mais sete artigos ao texto original, estendeu o prazo de concessão do benefício para até 15 de agosto de 1979 ,

\footnotetext{
${ }^{30}$ MEZAROBBA, Glenda. op. cit., p. 32.

31 BATISTA, Nilo. Aspectos jurídico-penais da anistia. Revista Encontros com a Civilização Brasileira, v. 19, p. 195-206, 1980.

${ }^{32}$ MEZAROBBA, Glenda. op. cit., p. 38.
} 
incluiu no art. 1 a possibilidade de anistia também para os crimes eleitorais, garantiu aos dependentes de anistiado falecido o direito às vantagens que lhe seriam devidas, previu a possibilidade de familiares de desaparecidos requererem uma declaração de ausência da pessoa, concedeu anistia também aos empregados de empresas privadas, que haviam sido punidos por participação em greves, e estabeleceu que os anistiados inscritos em partidos políticos legalmente constituídos poderiam votar e ser votados.

Requer-se, portanto, que se atente para dois pontos polêmicos que pautaram a concessão da anistia brasileira: (i) a compreensão do conteúdo dos crimes políticos, os quais somente seriam anistiados caso ainda não tivessem sido julgados, contrariando, portanto, o desenvolvimento teórico da anistia, o qual propõe o esquecimento do crime não-só no decorrer da ação penal quanto no momento da execução da pena, e (ii) a questão dos crimes conexos, os quais, segundo a lei, também seriam anistiados.

\section{O conceito de crime político}

Considera-se que o delito é a transgressão do ordenamento jurídico penal, e, ao lado dos delitos que lesionam o Estado, de forma genérica e indireta, existem outros que o atacam de modo direto e específico, ou seja, o Estado não é em si atacado pelo roubo, pela falsidade, pelo homicídio, da mesma maneira que pela traição, a espionagem, a insurreição armada contra os poderes do Estado. Apenas nestes últimos casos, temos o delito típico contra o Estado, o qual se denomina de crime político.

A distinção entre o crime político e o crime comum encontra-se: ${ }^{33}$

(i) na natureza do direito lesionado; o crime político é aquele que ofende um direito político, como, por exemplo, o que ataca os direitos primários de segurança do Estado (integridade do território, autonomia, forma de governo) ou os direitos políticos dos cidadãos (delito político impróprio);

(ii) no objeto ou no fim que o agente se propõe, ou seja, sempre que se constitua um fim político será político o crime;

(iii) nas circunstâncias que acompanham o crime, como o estado de guerra civil, de insurreição, de comoção pública, e

(iv) no critério do direito protegido combinado com o fim, por exemplo, matar um sentinela ou roubar um armamento militar são fatos que podem realizar-se por fins políticos ou por fins privados, com diversidade do direito violado nos dois casos.

${ }^{33}$ MAGGIORE, Giuseppe. Derecho penal. Bogotá: Temis, 1972. v. 3, p. 17-33. 
Desde que existe a figura do Estado, ainda que seja de forma incipiente, a agressão contra sua existência tem sido considerada como crime. Entretanto, a conceituação do crime político tem se mostrado muito frágil. O que se chama de defesa do Estado, muitas vezes, acaba na proteção de interesses de partidos, de classes, de indivíduos que, a partir do momento em que chegaram ao poder, ficam decididos a conservar-se a todo custo, seja por meio da violência ou do auxílio da legalidade. Por isso, não é difícil identificar-se a chamada "razão de Estado" como se fosse um acobertamento para ambições pessoais. Quanto mais ditatorial for um regime, mais aumentam as novas figuras de crimes políticos e se fazem mais severas as medidas repressivas; motivo pelo qual surge a desconfiança em relação aos crimes políticos. ${ }^{34}$

Por outro lado, apesar desses interesses, isso não impede que o Estado conserve em si algum valor moral, ou seja, quando representa, por exemplo, a coletividade organizada. A esse valor do Estado corresponderia o dever moral do indivíduo de prestarlhe obediência, de servir-lhe e de honrá-lo. É exatamente nesse dever que se encontra a justificativa para a incriminação do delito político.

Por isso, é preciso fazer certas distinções. Existem crimes políticos que atacam o Direito Natural, entendidos como os delitos contra a pátria, como cometer algum ato com o objetivo de colocar a pátria sob domínio estrangeiro, de pôr fim a sua independência, de dissolvê-la, de utilizar armas contra o próprio país, de espionar etc. $\mathrm{O}$ amor à pátria é um dever imposto pelo Direito Natural tal como o amor ao pai e à mãe. Ao passo que existem crimes políticos que não são contrários ao Direito Natural, portanto, não apresentam violação de deveres absolutos e imutáveis, como aqueles atos que tendem a alterar violentamente a constituição do Estado, a forma de governo, a ordem de sucessão ao trono, a impedir o Governo do exercício de suas funções etc.

De toda forma, o campo dos crimes políticos mostra-se um dos mais delicados da ciência criminal, pois, nesse caso, tem-se o risco de que a função penal se degenere e se transforme de um órgão de justiça em um instrumento de opressão e vingança.

No que diz respeito à anistia, pela sua própria natureza, ela é reservada, especialmente, para os crimes políticos. ${ }^{35}$ Por isso, a tendência legislativa, aplicada depois de um conflito, no sentido de ampliar os crimes suscetíveis de anistia, abrangendo até mesmo infrações de direito comum, é criticável e pode levar às conseqüências imprevisíveis. ${ }^{36}$

\footnotetext{
${ }^{34}$ MAGGIORE, Giuseppe. op. cit., p. 17-33.

35 Essa é a posição de Vidal Magnol: L'amnistie (...) elle est généralement une mesure politique d' apaisement employée pour les crimes et délits politiques ou de presse, pour certains délits fiscaux, ou contre le devoir militaire. Ver: MAGNOL, Vidal. Cours de droit criminel et de science pénitentiaire; 8. ed. Paris: Rosseau, 1935. p. 689.

36 Vidal Magnol comenta que, devido à soberania do legislador, a anistia pode ser concedida de uma maneira coletiva e geral a toda uma categoria de delinqüentes sem levar em consideração a natureza das infrações que foram cometidas; e que esse caráter geral e não individual da anistia apresenta graves inconvenientes,
} 
Disso resulta que a anistia vai perdendo sua tradicional característica (a vinculação aos crimes políticos), para se tornar uma medida de ordem subjetiva e pessoal, aplicada até para infrações de direito comum por justificativas que se relacionam ao criminoso e não ao delito.

No âmbito da doutrina brasileira, Aloysio Carvalho ${ }^{37}$ menciona que a índole do instituto da anistia efetivamente repele a extensão aos delitos comuns. Tratando-se de medida política, deveria aplicar-se, principalmente, aos delitos políticos. E, ao analisar o conteúdo da lei de anistia, de 1979, no que diz respeito a sua extensão, Nilo Batista ${ }^{38}$ defende que essa vinculava-se aos crimes políticos e que não poderia ser aplicável aos crimes comuns. De acordo com seu argumento, o próprio art. 57, inc. VI, da então Constituição Federal de 1969, no qual se fundamentava a anistia, mencionava que seria da competência exclusiva do presidente da República a iniciativa de leis que concedam anistia relativa a crimes políticos, ouvido o Conselho de Segurança Nacional, deixando claro, portanto, que a iniciativa restringia-se aos delitos políticos. E também reforça a sua posição utilizandose da Exposição de Motivos da mesma lei que estabelecia que não seria abrangido pela anistia quem tivesse sido condenado pela justiça por crime que não fosse estritamente político. A discussão maior, encontrava-se, porém, em que se poderia entender por "crime conexo ao crime político" tal como mencionava o art. 1 da referida lei.

Os crimes conexos são entendidos como delitos dependentes, de tal forma que possa existir um nexo entre os crimes, ou seja, que um dos delitos tenha sido cometido para realizar ou para ocultar outro delito, ou também para assegurar-se a si mesmo ou assegurar a outros o produto, o proveito ou a impunidade do delito. ${ }^{39}$

No caso específico desses crimes, que mantêm uma vinculação, essa conexão, que leva o processo a ser unificado, pode ser: (i) ideológica ou teleológica, quando o delito foi cometido com o intuito de assegurar a realização de outro delito; (ii) conseqüencial, nos casos em que o delito é praticado para ocultar outro delito, ou para assegurar para si ou

pois a lista de atos anistiados engloba até mesmo as infrações de direito comum e de caráter anti-social. Ver: MAGNOL, Vidal. op. cit., p. 689-690. No mesmo sentido, Pierre Bouzat lembra que os caracteres da anistia têm sido alterados e o seu campo de aplicação tem sido alargado, de tal forma que se estendeu a anistia a um número considerável de infrações de direito comum e de faltas disciplinares e, também se trouxe um problema de política criminal ao se anistiar infração que implica uma imoralidade ou um perigo social caracterizado. Ver: BOUZAT, Pierre. Traité théorique et pratique de droit penal. Paris: Dalloz, 1951. p. 540-541.

${ }^{37}$ CARVAlHO FILHO, Aloysio. Comentários ao código penal. Rio de Janeiro: Forense, 1958. v. 4, p. 103161.

${ }^{38}$ BATISTA, Nilo. Aspectos jurídico-penais da anistia. Revista Encontros com a Civilização Brasileira, v. 19, p. 195-206, 1980.

${ }^{39}$ MAGGIORE, Giuseppe; Derecho penal. Bogotá: Temis, 1972. v. 2, p. 184-187. 
para outrem o produto ou a impunidade do delito; ou (iii) ocasional, quando, por exemplo, o réu, após ter roubado a vítima, causa-lhe lesões corporais por maldade. ${ }^{40}$

No caso brasileiro, ao se observar o tratamento dado às leis de anistia anteriores a de 1979, foi possível observar que a jurisprudência já se manisfestou no sentido da possibilidade da aplicação da anistia aos delitos conexos desde que houvesse expressa menção na lei anistiadora. ${ }^{41}$ Mas, levando em consideração a natureza e gravidade do crime, a doutrina ${ }^{42}$ tem entendido que alguns crimes, apesar de conexos aos crimes políticos que são anistiados, deveriam escapar ao benefício.

Esse tema já suscitou duas decisões judiciárias importantes, logo no início da República, que foram analisados por Carvalho Filho. ${ }^{43}$ Uma reconhecia que o assassinato do coronel Francisco Chicuta, cometido por José Inácio Trindade Filho, na cidade de Passo Fundo, possuía conexão com um movimento político de rebeldia que havia sido iniciado naquela cidade e cujos responsáveis já haviam sido anistiados pelo ato de 1895. Esse entendimento tornou nula a pronúncia por crime comum de homicídio que, anteriormente, a justiça do Rio Grande do Sul tinha decretado contra Trindade Filho.

E a outra decisão mandava incluir entre os beneficiados pela anistia, de 1891, um ex-cadete, que tinha sido condenado pelo Tribunal Militar a 30 anos de prisão, pela tentativa de homicídio do seu superior, em co-autoria com outros companheiros de farda e alguns civis, na cidade de Belém (Pará). Naquela época, o Supremo Tribunal Federal entendeu que esse crime vinculava-se ao movimento armado que, logo após o cometimento do crime, iria ocorrer para a deposição do governador do Pará.

Em ambas as decisões, o então ministro Américo Lôbo foi voto vencido, pois se posicionava contrário à adoção da conexão para fins de anistia quando se tratasse do assassinato, do roubo, do incêndio e dos ataques ao pudor, porque, segundo seu ponto de vista, esses delitos jamais se confundiriam ou se misturariam aos crimes políticos; já

\footnotetext{
${ }^{40}$ Faustin Hélie já explicava que a conexão resulta de que os delitos são conexos dentro de três hipóteses: (i) eles foram cometidos ao mesmo tempo por distintas pessoas reunidas; (ii) eles foram praticados por pessoas diferentes, mesmo em tempo e lugares diversos, mas havia uma combinação entre eles; ou (iii) os delitos foram cometidos uns para facilitarem outros ou para assegurar a impunidade. Ver: HÉLIE, Faustin. Pratique criminelle des cours et tribunaux. 5. ed. Paris: Marchal Billard, 1887. p. 286-287.

${ }^{41}$ BRASIL. Supremo Tribunal Federal. A anistia concedida a delitos políticos só se estende a crime comum conexo quando expressamente determinado na lei que a concede. H.C. n. 29.797. Osvaldo Ribeiro Teixeira e outros. Relator: Min. Lafayette de Andrada. Acórdão de 10 de setembro de 1947. Revista Forense, Rio de Janeiro, v. 115, p. 210, jan. 1948.

${ }^{42}$ CARVAlHO FILHO, Aloysio. Comentários ao código penal. Rio de Janeiro: Forense, 1958. v. 4, p. $103-$ 161.

${ }^{43}$ Id. Ibid., p. 103-161.
} 
que aqueles não pertenceriam à categoria de atos inspirados pelo patriotismo, tal como seriam os crimes políticos. ${ }^{44}$

Mas, em 1916, por meio do Decreto Legislativo n. 3.102, de 13 de janeiro, a anistia a crimes políticos, vinculados a movimentos políticos que tinham ocorrido no Estado do Ceará, entre 1913 e 1915, expressamente excetuava do benefício os crimes contra a propriedade, os de incêndio, e os que se manifestassem por atos de barbárie, crueldade ou vandalismo, ainda que conexos com crimes políticos ou praticados por ocasião dos movimentos revolucionários anistiados; ${ }^{45}$ prevalecendo, assim, naquela circunstância a restrição que havia sido defendida pelo ministro Américo Lôbo.

Porém, a seqüência de anistias brasileiras denuncia o predomínio da norma irrestrita, tal como recomendavam as duas decisões judiciárias anteriormente mencionadas. De tal forma que a ressalva do decreto legislativo, de 1916, não criou precedentes, e as anistias de 1930, de $1934^{46}$ e de 1945 dispuseram, inequivocamente, sobre a extensão do benefício aos delitos conexos. ${ }^{47}$

Em 10 de setembro de 1945, por meio do Decreto-Lei n. 7.943, uma nova anistia foi concedida aos acusados por crimes de injúria aos poderes públicos e também para os responsáveis por crimes de qualquer natureza, considerados políticos ou não, ocorridos durante ou logo após a realização de comícios, passeatas ou outras manifestações políticas, que também alcançava os crimes conexos. ${ }^{48}$

${ }^{44}$ Para Américo Lôbo: “A lei de anistia, relativa a movimentos revolucionários, por mais genérica que seja, não compreende assassinatos ou tentativas de assassinatos premeditados, fria e covardemente realizados a desoras, numa rua de lampiões apagados de indústria, com emboscada, disfarce, traição, surpresa e superioridade de armas". Ver: CARVALHO FILHO, Aloysio. op. cit., p. 103-161.

45 BRASIL. Decreto Legislativo n. 3.102, de 13 de janeiro de 1916. "Concede anistia a todos os civis e militares que, direta ou indiretamente, se envolverem nos movimentos revolucionários do Estado do Ceará. Art. 1, § 2 Ficam excluídos desta anistia os crimes contra a propriedade, os de incêndios e os que se constituírem por atos de barbárie, crueldade ou vandalismo, ainda mesmo quando sejam conexos com outros crimes de natureza política, ou tenham sido praticados por ocasião daqueles movimentos revolucionários, ou os respectivos autores tenham agido por móvel político, ou sob a excitação das paixões partidárias, ou com objetivo político".

${ }^{46}$ A anistia concedida em 1934 relaciona-se à revolução constitucionalista de 1932. Ver: BRASIL. Decreto n. 24.297, de 28 de maio de 1934, art. 2: "São isentos de toda responsabilidade os participantes do surto revolucionário, verificado em São Paulo, 9 de julho de 1932, e suas ramificações em outros Estados. Parágrafo único. Compreendem-se nesta isenção qualquer outro crime político e os que lhe forem conexos, praticados até esta data".

47 Ver Decretos. ns. 19.395, de 8 de novembro de 1930, 24.297, de 28 de maio de 1934, e Decretos-leis ns. 7.474, de 18 de abril de 1945, e 7.943, de 10 de setembro de 1945. A anistia do Decreto-Lei n. 7.769, de 23 de julho de 1945, relativa aos militares que integravam a Força Aérea Brasileira (FEB), compreendia os crimes comuns, sendo, pois, supérflua a alusão aos crimes conexos, o mesmo ocorrendo com a anistia do Decreto n. 20.558, 24 de outubro de 1931, que concedia anistia aos crimes eleitorais praticados até 24 de outubro de 1930. O Decreto legislativo n. 18, de 13 de julho de 1951, concedeu anistia aos condenados ou processados "por motivo de greve" simplesmente.

${ }^{48}$ O Decreto-Lei n. 7.943, de 10 de setembro de 1945, limitava a anistia aos fatos ocorridos até a data em que se permitira a arregimentação partidária (28 de maio de 1945). O conceito dos crimes anistiáveis repousava no 
Apesar dos exemplos acima, Aloysio Carvalho ${ }^{49}$ afirmava que, quando se tratasse de anistia, não era prudente fixar em abstrato a existência de conexão nos casos de crimes políticos. O ideal seria o exame, em cada caso concreto, da relação de dependência entre um fato e outro, observando-se, em particular, o objetivo político que os vinculava, isto é, a intenção política do agente. E, em assim não sendo possível, ao menos que se adotasse o critério das circunstâncias objetivas do crime, tal como havia sido estabelecido no Decreto legislativo n. 3.102 de 1916.

Por ocasião da elaboração da Lei de Anistia, de 1979, como os presos políticos encontravam-se impedidos de participar diretamente do debate, eles entregaram manifestações ao senador Teotônio Vilela, nas quais criticavam os principais artigos do projeto de lei e classificavam como discriminatória a anistia; apontavam para o fato de que o objetivo da lei era garantir uma ampla, geral, irrestrita e prévia anistia aos torturadores do regime ao incluir a expressão "crime conexo ao crime político".

Arespeito dos crimes conexos, Hélio Bicudo ${ }^{50}$ manifestou-se, posteriormente, da seguinte forma:

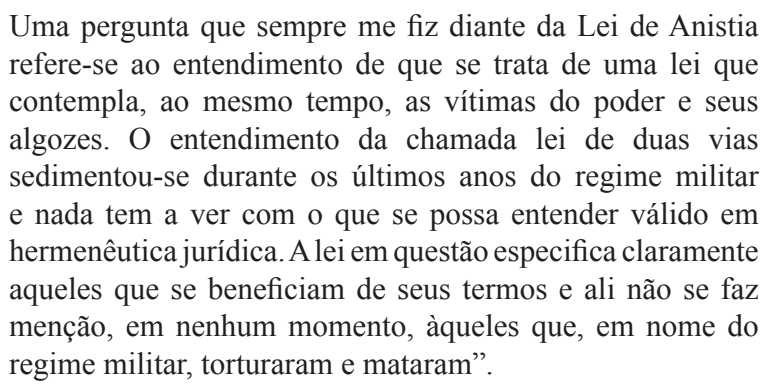

A preocupação de Hélio Bicudo voltava-se, essencialmente, sobre a anistia concedida aos perpetradores das violações dos Direitos Humanos, ou seja, sobre a interpretação que havia sido feita do $\S 2$ do art. 1, pois, conforme o entendimento vigente na época, a lei estendia a anistia àqueles que houvessem cometido crimes conexos aos delitos políticos, interpretados como os crimes de qualquer natureza que estivessem relacionados com crimes políticos ou praticados por motivação política.

E, em sua análise, o referido jurista chegou à conclusão de que não poderia haver conexidade de crimes que atingem bens jurídicos diversos, pois, no caso concreto

Decreto n. 7.474, de 18 de abril de 1945, em que se consideravam conexos, para os efeitos da anistia, os crimes comuns praticados com fins políticos.

49 CARVAlHO FILHO, Aloysio. Comentários ao código penal. Rio de Janeiro: Forense, 1958. v. 4, p. 103161.

${ }^{50}$ BICUDO, Hélio. Lei de anistia e crimes conexos. Folha de São Paulo, 6 de dezembro de 1995. Caderno Tendências e Debates. p. 1-3. 
não se poderia encontrar equivalência de causas ou motivações entre o ato daquele que afronta o sistema político prevalente e o daquele que o reprime, pois o primeiro anseia por mudanças e atua em conseqüência de suas expectativas; enquanto que o segundo quer manter o status quo e age, portanto, de acordo com os interesses que ele pretende preservar.

A fim de que se configure a conexidade, um crime deve ser pressuposto do outro. De tal forma que, se não for identificada a unidade delitiva, que é o fundamento do instituto, não se poderia pensar na existência de crimes conexos. E haveria, portanto, a caracterização de crimes independentes, porque constituem caminhos diferentes e perseguem objetivos que não se confundem.

Nilo Batista, ${ }^{51}$ que também manifestou-se no mesmo sentido, lembrou em primeiro lugar que a conexão é um instituto de Direito Processual Penal; significando que, quando existe a presença de certas circunstâncias (ideológica, conseqüencial ou ocasional - as quais já apontadas acima), sugere-se a reunião dos referidos processos pertinentes a vários delitos e estende-se competência do juiz de um deles para que este processe e julgue os demais. No entanto, o conceito de crime conexo a crime político, que se busca na interpretação de Lei de Anistia, de 1979, é um conceito material e não-processual, que se relaciona com a própria natureza do crime.

E os crimes conexos aos crimes políticos deveriam ser entendidos como aqueles que só atingem bens jurídicos comuns e que estão em uma relação de meio a fim para com os propósitos dos crimes políticos puros, prevalecendo, assim, uma visão objetiva fundamentada na relação entre meio e fim..$^{52}$

Então, para a definição de crime conexo ao crime político, deve-se aplicar o mesmo critério objetivo que prevalece para o próprio crime político. No sentido de que a anistia alcança não-só os delitos comuns, que sejam meio para a prática de crimes políticos, ou para escapar às penas desses (o chamado crime político impróprio), bem como quaisquer outros (ainda que não-relacionados objetivamente com um crime político), desde que praticados com motivação política, ou seja, a finalidade da motivação política é que determina a existência de um crime conexo ao político.

E, por essa razão (a finalidade da motivação política), Nilo Batista ${ }^{53}$ mostrase categórico ao concluir que não se poderia estender o benefício da anistia aos agentes do Estado que atuaram na repressão militar praticando a tortura, porque esse delito não seria

\footnotetext{
${ }^{51}$ BATISTA, Nilo. Aspectos jurídico-penais da anistia. Revista Encontros com a Civilização Brasileira, v. 19, p. 195-206, 1980.

${ }^{52}$ SANTOS, Boaventura de Souza. Os crimes políticos e a pena de morte. Revista de Direito Penal, v. 1, 1971; pud: BATISTA, Nilo. Aspectos jurídico-penais da anistia. Revista Encontros com a Civilização Brasileira, v. 19, p. 195-206, 1980.

${ }^{53}$ BATISTA, Nilo. op. cit., p. 195-206.
} 
decorrência lógica da motivação política que levava os movimentos armados às táticas de guerrilhas urbana e rural:

(...) se delito conexo aos políticos é aquilo que aqui se estudou; se a anistia é o instituto de que se tratou nas linhas acima, não estão abrangidos por ela os torturadores e homicidas de presos políticos. A tortura e o homicídio de um preso não são crimes políticos, nem são crimes conexos a crimes políticos, objetiva e subjetivamente. São crimes comuns (...) que estão a merecer processo e julgamento.

A anistia de dupla via

Um outro tema recorrente na análise da Lei de Anistia brasileira, de 1979, diz respeito à dupla via, ou concessão de benefícios recíprocos aos agentes estatais e aos opositores políticos. Apesar das discussões que foram levantadas, em 1979, por ocasião das propostas de emenda ao projeto de lei de anistia, a imagem que se fixou em meio à sociedade foi de que a partir da anistia, com o retorno dos exilados políticos, a reconciliação e a pacificação dos espíritos seriam realmente possíveis e que, utilizando-se do argumento do mal menor, ainda que também se concedesse anistia aos agentes estatais, este mal seria justificável em nome da transição política.

A proposição de que a adoção de uma lei de anistia, que dispensa a responsabilização pelos crimes cometidos no passado, mostra-se mais conveniente do que se suportar um período de conflito e de transição violenta em muito se assemelha à chamada Teoria do Mal Menor, pois, de acordo com essa justificação moral, quando se está diante de dois males, há que se optar sempre pelo menor. Se aplicada para o tema das anistias, a Teoria do Mal Menor tenderia a explicar que, diante (i) do esquecimento dos crimes que foram cometidos e (ii) de uma transição política violenta, o melhor seria a opção pela anistia, um mal menor.

Porém, a utilização desse argumento é questionável. Hannah Arendt $^{54}$ lembra que a sua fraqueza está em que, ainda que se tenha escolhido o mal menor, este continua a ser um mal. E, com o passar dos anos, a tendência é que isso seja raramente lembrado pela população. E aí se encontra o perigo: o risco de se esquecer que se praticou um mal ainda que em pequena dimensão.

\footnotetext{
${ }_{54}$ Para Arendt: “(...) A aceitação de males menores é conscientemente usada para condicionar os funcionários do governo, bem como a população em geral, a aceitar o mal em si mesmo. Para dar apenas um dentre muitos exemplos: a exterminação dos judeus foi precedida por uma seqüência muito gradual de medidas antijudaicas, cada uma das quais foi aceita com o argumento de que a recusa a cooperar pioraria ainda mais a situação - até que se atingiu um estágio em que nada pior poderia possivelmente ter acontecido". Ver: ARENDT, Hannah. Responsabilidade e julgamento. São Paulo: Companhia das Letras, 2004. p. 99.
} 
Assim, a Anistia brasileira, de 1979, que liberava e concedia o esquecimento tanto dos crimes políticos, praticados pelos cidadãos contra o Estado, quanto das violações dos Direitos Humanos, perpetradas pelo Estado contra seus cidadãos, foi reconhecida como de "mão dupla" ou de "dupla via". O que é preciso observar, no entanto, é se o fundamento da anistia de dupla via repousa realmente em justificativas teóricas sobre crimes políticos e violações dos Direitos Humanos.

Um primeiro ponto que deve ser reforçado é a distinção entre: (i) leis de anistia oferecidas pelos Estados aos seus opositores, normalmente por crimes políticos, e (ii) aquelas que concedem imunidade ao próprio Estado pelos atos cometidos por seus agentes. $\mathrm{O}$ entendimento é de que apenas o primeiro caso encontra-se no rol dos direitos do Estado, devido ao seu papel de vítima da agressão e de garantidor das leis penais estatais, e esse direito não deveria se estender a situações nas quais o próprio Estado, por meio dos seus agentes, é o perpetrador das violações. ${ }^{55}$

Acrescente-se também que, referidas leis, que liberam de julgamento as condutas cumpridas sob o comando do Estado, permitem ao Estado julgar o seu próprio caso, um resultado inconsistente com os princípios gerais de direito que proíbem o autojulgamento. ${ }^{56}$ Esse princípio deveria ser aplicável em casos de auto-anistias concedidas por um Governo para as suas próprias forças: tais anistias configuram-se em uma versão simplificada de autojulgamento (ainda que em sentido figurado, pois nenhum julgamento de fato é permitido nestes casos) e, portanto, estariam proibidas pelos princípios gerais de direito.

No período ditatorial a justificativa que se difundia sobre a prática das graves violações dos Direitos Humanos era a de que os atos haviam sido cometidos em situações nas quais a responsabilidade moral do Estado, como guardião da segurança nacional, estivesse comprometida em decorrência das ações de cidadãos que atuavam por razões políticas, ${ }^{57}$ dando motivo, portanto, à aplicação da anistia para essas circunstâncias.

No entanto, sob esse aspecto, a aceitação da anistia de dupla via padece de um ponto de vista errado sobre o conceito de violações dos Direitos Humanos e crimes políticos, pois essa anistia diverge do conceito político-legal universalmente aceito de que as anistias são aplicáveis aos crimes políticos praticados pelos cidadãos. Igualar genuínas violações dos Direitos Humanos praticadas por agentes estatais aos atos criminosos

${ }^{55}$ GOLDMAN, Robert. Amnesty laws and international law: a specific case. In: INTERNATIONAL Comission of Jurists. Seminar on Justice Not Impunity. Geneva: ICJ, 1992.

${ }^{56}$ A Corte Permanente de Justiça Internacional, antecessora da Corte Internacional de Justiça, em 1925 no Caso Frontier between Iraq and Turkey utilizou a regra de que ninguém pode ser o juiz de seu próprio processo. Ver: art. 3, § 2, Treaty of Lausenne, 1925, CPJI, de 21 de novembro de 1925.

${ }^{57}$ MERA, Jorge. Chile: truth and justice under the democratic government. In: ARRIAZA, Naomi Roth (Org.). Impunity and human rights in international law and practice. New York: Oxford University Press, 1995. p. 171-184. 
cometidos por grupos armados dissidentes distorce a natureza específica dos primeiros, ou seja, o efeito é a perversão do verdadeiro conceito de Direitos Humanos.

As violações dos Direitos Humanos sempre estiveram limitadas às ações do Estado. Os Direitos Humanos surgem historicamente como uma demanda para limitar o poder do Estado e representam uma restrição à soberania dos Estados. Legalmente, os Direitos Humanos são obrigações assumidas pelo Estado tanto no âmbito interno quanto internacional; na verdade, a necessidade de uma proteção internacional dos Direitos Humanos deriva da falta de proteção a tais direitos dentro do próprio Estado.

A idéia de que existem certos valores do comportamento humano que não-só o Estado mas também todos os atores políticos devem respeitar tem se tornado algo sagrado na consciência pública. Essas regras de comportamento humano derivam parcialmente das normas de Direitos Humanos e das normas de Direito Internacional humanitário. Em tempos de paz, elas governam todos os atores políticos, governamentais e não-governamentais; e, no caso de conflitos armados, qualquer que seja a sua natureza, elas são obrigatórias para todas as forças combatentes e para pessoas que não tomam parte nas hostilidades (civis).

Os atos de terrorismo ou outras ações ilegítimas cometidas por razões políticas não podem ser utilizados para buscar justificar as violações dos Direitos Humanos cometidas pelos Estados, ${ }^{58}$ como se representassem uma troca para se alcançarem concessões. As verdadeiras razões para a proposição da lei de anistia, que trata de crime político e demais crimes conexos a ele, são encontradas em considerações políticas. Elas estão vinculadas ao objetivo central de evitar atritos com as Forças Armadas que poderiam colocar em risco o sucesso da transição.

O perigo é que, ao privilegiar essas considerações políticas, a impressão que restou é que, ao invés do terror de Estado, o que aconteceu no Brasil foi uma luta entre grupos rivais, como se configurasse um conflito armado nos termos do Direito Internacional humanitário, que, chegando ao fim, autorizasse a aplicação de uma anistia.

Há que se salientar a respeito da aplicação de anistia ao final de conflitos armados, o Direito Internacional e a prática doméstica dos Estados em determinados momentos permitem, e até em certos casos requerem, a efetivação destas; mas, apesar de tal encorajamento estar codificado em um dos principais documentos do Direito Internacional humanitário, ${ }^{59}$ essas anistias devem ser analisadas de forma distinta daquelas

\footnotetext{
58 MERA, Jorge. op. cit., p. 171-184.

59 Verificar o Protocolo Adicional n. II às Convenções de Genebra de 1949 relacionado à proteção das vítimas de conflitos armados não-internacionais, de 8 de junho de 1977, art. 6 (5): "Quando da cessação das hostilidades, as autoridades no poder procurarão conceder a mais ampla anistia às pessoas que tiverem tomado parte no conflito armado, ou que estiverem privadas de sua liberdade por motivos relacionados com o conflito armado, quer estejam internadas ou detidas".
} 
relacionadas às violações dos Direitos Humanos e aos crimes contra a humanidade. Sobre a questão das anistias, um recente posicionamento do Comitê Internacional da Cruz Vermelha ${ }^{60}$ a respeito das Convenções de Genebra confirmou que as anistias mencionadas no Protocolo Adicional n. II, de 1977, foram feitas para serem aplicadas somente àqueles que participaram de hostilidades e, não, para os que violaram o Direito Internacional.

Assim, se adotada num contexto amplo como no caso da transição brasileira, essa anistia desvaloriza a busca pela verdade, não apenas em relação às violações dos Direitos Humanos mas, também, no que diz respeito aos sérios crimes que foram cometidos por cidadãos contra o Estado e os membros das Forças Armadas. ${ }^{61}$

Os grupos que atacaram os militares e a Polícia nunca tiveram uma organização e resistência que fosse capaz de criar uma situação na qual as regras do Direito Internacional humanitário fossem aplicadas no País. ${ }^{62} \mathrm{O}$ Estado nunca esteve em perigo, nem as ações desses grupos criaram um senso generalizado de insegurança na população por causa dos seus atos. Por isso, torna-se fundamental a exata distinção do que o Direito Internacional humanitário denomina de tensão interna e de conflito armado não-internacional.

Muitos Estados no curso de suas histórias passaram por tensões internas, algumas vezes tão sérias que chegaram a ameaçar as suas próprias estruturas. Essas situações, caracterizadas por atos de revolta e violência cometidos por grupos mais ou menos organizados, lutando contra as autoridades ou entre si próprios, são distintas daquelas abarcadas pelos conflitos armados não-internacionais, nos quais a violência é muito mais intensa. Com o objetivo de trazer esses confrontos internos a um fim e de restaurar a ordem, as autoridades freqüentemente utilizam-se das forças policiais e até

\footnotetext{
${ }^{60}$ SLYE, Ronald C; "The legitimacy of amnesties under international law and general principles of angloamerican law: is a legitimate amnesty possible? Virginia Journal of International Law, v. 43, n. 1 p. 178, 2002.

${ }^{61}$ Sobre os crimes que foram cometidos pelos grupos armados, Gaspari sugere que: “(...) Pode-se ter uma visão do que aconteceu ao terrorismo brasileiro nos 23 meses que vão de agosto de 1968 ao fim do primeiro semestre de 70 buscando-se (...) as cinco principais ações terroristas do período, a saber: 1. o assalto ao trem pagador da ferrovia Santos-Jundiaí (10 de agosto de 1968), pela ALN; 2. o ataque ao QG do II Exército (26 de julho de 1968), pela VPR; 3. o assassinato do capitão Chandler (12 de outubro de 1968), pela VPR; 4. o roubo do cofre de Adhemar de Barros (11 de maio de 1969), pela VAR-Palmares, derivada da VPR e do Colina e, 5. o seqüestro de Elbrick (4 de setembro de 1969), pelo condomínio da Dissidência Universitária com a ALN". Ver: GASPARI, Elio. A ditadura escancarada. São Paulo: Companhia das Letras, 2002. p. 161-162.

${ }^{62} \mathrm{Na}$ análise de Elio Gaspari: "No caso brasileiro, faltou ao surto terrorista a dimensão que lhe foi atribuída. Só no segundo semestre de 1970 explodiram 140 bombas nos Estados Unidos, número superior, de longe, a todas as explosões ocorridas no Brasil. Em 1971, na Irlanda, detonaram-se mais de mil bombas (...)”. E, em outra passagem ao analisar a Guerrilha do Araguaia: "O que se deu no Araguaia foi o paroxismo do choque dos radicalismos ideológicos que, com seus medos e fantasias, influenciaram a vida política brasileira por quase uma década. A esquerda armada supusera que estava no caminho da revolução socialista, e a ditadura militar acreditava que havia uma revolução socialista a caminho". Ver: GASPARI, Elio. op. cit., p. 18 e 406.
} 
mesmo das Forças Armadas. O resultado inevitável é um enfraquecimento do Estado de Direito, marcado por sérias violações dos Direitos Humanos cometidas em larga-escala.

Aceita-se que os governos declarem um estado de exceção e, desde que a situação assim o requeira, que sejam tomadas certas atitudes, que se distanciam das regras estabelecidas pelo Direito Internacional dos Direitos Humanos, e se suspendam determinados direitos. Existem, no entanto, certos direitos fundamentais inerentes à dignidade humana, os chamados direitos inalienáveis, aos quais nenhuma derrogação é permitida.

O que se observa, porém, é que as garantias oferecidas por esses direitos aos indivíduos envolvidos em uma tensão interna tornaram-se inadequadas, pois não cobrem a totalidade das situações que advêm de uma tensão interna. Tanto é que iniciativas no âmbito internacional têm sido tomadas a fim de se fornecer uma melhor proteção nos casos em que existe uma suspensão aos Direitos Humanos devido à violência interna, na qual as atrocidades passam a ser cometidas.

É verdade que todos os Estados têm uma liberdade relativa para decidirem se uma determinada situação apresenta um perigo para o povo e se é necessário que se declare o estado de exceção; essa opção, no entanto, sujeita-se a condições de forma e substância. Não importa quão sérias sejam as circunstâncias que tenham levado o Estado a tomar essas medidas, ele não poderá se afastar de certas regras fundamentais.

De acordo com o projeto para um tratado que verse sobre a responsabilidade do Estado, ${ }^{63}$ o estado de exceção pode ser invocado por um Governo somente se ele representa o único meio de salvaguardar os interesses do Estado contra um perigo grave e iminente. A gravidade da situação deve ser de tal forma que, a fim de manter a ordem pública e evitar o risco que envolve a própria existência do Estado, o recurso à legislação de emergência seja inevitável.

$\mathrm{O}$ art. 21 do referido projeto estabelece que exime-se de responsabilidade o Estado pelas violações cometidas por ele quando se tratar de uma medida legal de autodefesa. No entanto, em sua análise sobre o tema, Crawford ${ }^{64}$ aponta que isso não significa que a autodefesa do Estado preclui a responsabilidade do mesmo em todas as condutas ou em relação a todas as obrigações; pois as Convenções de Genebra de 1949, e o Protocolo Adicional n. 1, de 1977, aplicam-se igualmente para todos os Estados-membros durante um conflito armado internacional, e as convenções sobre Direitos Humanos que contêm regras sobre não-derrogações de direitos, mesmo em períodos de emergência,

\footnotetext{
${ }^{63}$ The draft on responsibility of States for internationally wrongful acts, adotado pela Comissão de Direito Internacional, em 9 de agosto de 2001.

${ }^{64}$ CRAWFORD, James. The international law comission's articles on State responsibility. Introduction, text and commentaries; 3. ed. Cambridge: Cambridge University Press, 2005. p. 166.
} 
também continuam válidas quando se trata de períodos de tensão interna; por isso não são capazes de retirar a responsabilidade do Estado quando da utilização de condutas arbitrárias.

Daí surgirem o que Momtaz ${ }^{65}$ chama de áreas cinzas em relação ao Direito Internacional dos Direitos Humanos que se aplicam em períodos de tensão interna e que se vinculam, principalmente, às prisões e suspensões das garantias processuais penais, pois, por exemplo, as autoridades, enfrentando uma tensão interna, geralmente invocam considerações de segurança como fundamento para a prisão de indivíduos selecionados nos círculos políticos, no movimento sindical e na imprensa. Os períodos de prisão são estendidos indevidamente, e muitas vezes os presos recebem maus-tratos, são freqüentemente deixados em isolamento, sem possibilidade de comunicação com um defensor ou com a família. Há casos em que as autoridades nem sequer anunciam a prisão (seqüestros). ${ }^{66}$

No âmbito internacional, algumas regras foram preparadas para tratar da prisão arbitrária e da detenção extrajudicial, a fim de melhorar a proteção aos detidos, como, por exemplo, o Standard minimum rules for the treatment of prisioners, adotado em 30 de agosto de 1955 pelo primeiro Congresso da ONU sobre a prevenção do crime e o tratamento do ofensor, o qual foi posteriormente atualizado por meio de uma resolução da Assembléia Geral da ONU denominada Body of principles for the protection of all persons under any form of detention or imprisonment.$^{67}$ Além disso, tanto o Pacto Internacional de Direitos Civis e Políticos quanto a Convenção Americana de Direitos Humanos contêm previsões assegurando os direitos fundamentais dos acusados tanto no período da detenção quanto no julgamento.

Assim, a definição entre a configuração de uma tensão interna e de um conflito armado não-internacional torna-se extremamente importante, pois será a partir desse enquadramento que serão aplicadas as regras de Direitos Humanos (ou de Direito Internacional dos Direitos Humanos) e as normas oriundas de um conflito armado (Direito Internacional humanitário). Celso Mello ${ }^{68}$ já alertava para a dificuldade de se definir entre

\footnotetext{
${ }^{65}$ MOMTAZ, Djamchid. The minimum humanitarian rules aplicable in periods of internal tension and strife. International Review of the Red Cross, v. 324, p. 455-462, 1998.

${ }^{66}$ As irregularidades nos procedimentos penais são comuns em períodos de tensão interna. O direito do acusado de receber um julgamento justo diante de uma corte independente e imparcial normalmente é ignorado. Existem restrições quanto ao direito de defesa; o acusado dificilmente tem acesso aos seus arquivos e lhe é negada informação quanto aos motivos de sua prisão e das acusações que pesam sobre ele.

67 UN General Assembly Resolution 43/173, de 9 de dezembro de 1988.

${ }^{68}$ Nas palavras de Celso Mello: "Não se pode deixar de frisar que ao se classificar uma sublevação em um determinado estágio, há aqui um alto grau de subjetividade”. Ver: MELLO, Celso D. de Albuquerque. Direitos humanos e conflitos armados. Rio de Janeiro: Renovar, 1997. p. 377.
} 
a aplicação de um ou outro ramo do Direito, já que eles determinam alguns pontos bastante distintos entre si.

Por exemplo, no caso do Direito Internacional dos Direitos Humanos, o direito à vida é garantido com um alto nível de proteção, ao passo que no Direito Internacional humanitário, o direito de atirar em um combatente é formalmente reconhecido. E, mais precisamente, no âmbito do Direito Internacional dos Direitos Humanos, a responsabilidade pelas violações que são cometidas são impostas ao Estado, enquanto que, nos crimes de guerra (e nos crimes contra a humanidade e genocídio), ao se aplicar o Direito Internacional humanitário, principalmente, os indivíduos é que são considerados responsáveis pelos crimes.

No mundo há uma progressão óbvia entre as situações de paz e estabilidade para instabilidade política e social, envolvendo protestos populares e perturbações da ordem pública, outras nas quais grupos organizados envolvem-se com práticas terroristas e insurreição, e aquelas nas quais existe uma linha de fronteira entre as forças do Governo e as forças opositoras em que cada uma delas controla parte do território nacional. Essa complexidade de situações reflete-se em distintas regras de Direito Internacional a serem aplicáveis diante do caso concreto. ${ }^{69}$

As regras gerais de proteção dos Direitos Humanos são claramente aplicáveis a situações de normalidade, sujeitas apenas às limitações usuais com respeito à segurança nacional, ordem pública e moralidade pública. Quando o nível de distúrbio é suficiente para colocar em risco a vida da nação e, por conseqüência, o gozo dos direitos por parte da população, os Estados são autorizados, sob os auspícios dos Direitos Humanos, a declarar um estado de exceção e a derrogar algumas das obrigações vinculadas aos Direitos Humanos; ${ }^{70}$ se for possível estabelecer que aquela derrogação é necessária e que as medidas são proporcionais ao risco apresentado contra o Estado e os direitos dos cidadãos. $^{71}$

\footnotetext{
${ }^{69}$ HADDEN, Tom; HARVEY, Colin. The law of internal crisis and conflict. International Review of the Red Cross; v. 833, p. 119-133, 1999.

${ }^{70}$ É o que dispõe, por exemplo, a Convenção Americana de Direitos Humanos em seu art. 27, § 1: "Em caso de guerra, de perigo público, ou de outra emergência que ameace a independência ou segurança do EstadoParte, este poderá adotar disposições que, na medida e pelo tempo estritamente limitados às exigências da situação, suspendam as obrigações contraídas em virtude desta Convenção, desde que tais disposições não sejam incompatíveis com as demais obrigações que lhe impõe o Direito Internacional (...)”. E, também no mesmo sentido encontra-se o art. 4 (1) do Pacto Internacional de Direitos Civis e Políticos.

${ }^{71}$ Porém, tanto o art. 4 (2) do Pacto Internacional de Direitos Civis e Políticos quanto o art. 27, § 2 da Convenção Americana de Direitos Humanos estabelecem, categoricamente, quais são os direitos e garantias fundamentais que não podem ser afastados ainda que o Estado viva um período de instabilidade ou tensão interna, como o direito à vida, o direito à integridade pessoal, a liberdade de consciência e de religião, os direitos políticos etc.
} 
Quando a situação se deteriora e chega a um conflito armado, as regras do art. 3 Comum às Convenções de Genebra, de $1949^{72}$ tornam-se aplicáveis e impõem certas obrigações para ambos os lados do conflito. Essas obrigações assemelham-se aos direitos não-derrogáveis constantes das principais convenções de Direitos Humanos, em particular a obrigação de tratar com dignidade aqueles que não tomam parte nas hostilidades (civis não-combatentes).

E, se o conflito toma proporções em que forças organizadas de ambos os lados tomam controle de parte do território nacional, as regras do Protocolo n. II de 1977, Adicional às Convenções de Genebra de 1949, ${ }^{73}$ passam as ser aplicáveis, as quais estabelecem a proteção às vítimas de conflitos armados não-internacionais.

Ressalta-se que, obviamente, a categorização acima apresentada é uma versão simplificada da realidade, no sentido de que os elementos, os graus de perturbação e a gravidade do conflito assumem distintas variáveis diante do caso concreto. E nem sempre se torna evidente o momento no qual as regras fundem-se ou transformam-se no que diz respeito às derrogações aos Direitos Humanos ou na adoção das regras do Direito Internacional humanitário.

Mas a importância de se saber enquadrar determinado acontecimento como uma violação dos Direitos Humanos (no âmbito das derrogações e da tensão interna) ou como um crime de guerra (porque se está diante de um conflito armado nãointernacional ou uma guerra civil) relaciona-se diretamente com o tema da anistia, porque, conforme observado anteriormente, existe uma divergência entre as normas oriundas do Direito Internacional dos Direitos Humanos e aquelas derivadas do Direito Internacional humanitário, no que diz respeito à anistia.

Em um período de tensão interna, os defensores dos Direitos Humanos, normalmente, observam que as graves violações dos Direitos Humanos deveriam ser submetidas à persecução criminal e à punição e se mostram determinantemente contrários à anistia. ${ }^{74} \mathrm{E}$, por outro lado, o Direito Internacional humanitário, que trata sobre o direito

\footnotetext{
72 De acordo com art. 3 Comum às Convenções de Genebra de 1949, permanecem proibidos em relação aos não combatentes os atentados à vida e à integridade física, as tomadas de reféns, as ofensas à dignidade das pessoas, especialmente os tratamentos humilhantes e degradantes, as condenações e execuções sem julgamento prévio, etc.

73 O art. 1 (1) do Protocolo n. II de 1977, Adicional às Convenções de Genebra de 1949, estabelece que este se aplica aos conflitos que se desenrolem em território de uma Alta Parte contratante, entre suas forças armadas e as forças armadas dissidentes, ou grupos armados organizados que, sob a chefia de um comandante responsável, exerçam sobre uma parte de seu território um controle tal que lhes permita levar a cabo operações militares contínuas e concertadas e; contrariamente, dispõe o art. 1 (2) do referido Protocolo que este não se aplica às situações de tensão e perturbação interna, tais como motins, atos de violência isolados e esporádicos e outros atos análogos, que não são considerados conflitos armados.

74 Essa é a abordagem que vem sendo aplicada, por exemplo, pela Comissão Interamericana de Direitos Humanos que tem repetidas vezes tomado a posição de que a persecução criminal e a punição dos acusados de terem
} 
aplicável em conflitos armados, favorece a liberação dos prisioneiros e a concessão de anistias para todos os combatentes que participaram de uma determinada hostilidade. ${ }^{75}$ Essa previsão, no entanto, deve ser analisada de acordo com os artigos-padrão das quatro Convenções de Genebra de 1949, os quais requerem de todos os Estados que apliquem sanções às graves violações às normas estabelecidas naqueles tratados.

A utilidade dessa distinção entre tensão interna e conflito armado nãointernacional serve para demonstrar que a justificativa da "dupla via" de uma lei de anistia coaduna-se com os propósitos do Direito Internacional humanitário, ou seja, quando há efetivamente a formação de um conflito, que opõe grupos armados, e conquista de território e que, ao final, beneficiam-se ambos os lados. E, por conseqüência, a lógica dessa "dupla via" não se repete quando se trata de uma tensão interna, tal como se configurou no regime militar brasileiro, na qual o Estado é chamado a conter uma revolta que não chega a abalar as suas próprias estruturas e se mantém aplicável o Direito Internacional dos Direitos Humanos que defende a responsabilização pelos atos cometidos em desacordo com a normativa internacional.

9 A Lei de Anistia brasileira e a interação entre as jurisdições nacional e internacional

A temática da Lei de Anistia relaciona-se também ao conflito existente entre as disposições do Direito interno e as responsabilidades assumidas pelo Estado na esfera internacional no que diz respeito à proteção dos Direitos Humanos. Passa-se a seguir, portanto, à análise da interação entre a jurisdição nacional e internacional com o propósito de verificar o conteúdo desses problemas e as eventuais soluções teóricas.

As Constituições contemporâneas, em geral, têm se mostrado mais propensas ao processo normativo internacional, que foi desenvolvido ao longo do século $\mathrm{XX}$, no âmbito da proteção dos Direitos Humanos, a fim de reconhecerem os tratados e garantirem eficácia jurídica aos mesmos na esfera doméstica. E esse fenômeno acaba por gerar uma atribuição de funções aos órgãos internos dos Estados para que estes possam harmonizar e assegurar a realização dos objetivos propostos nos tratados de Direitos Humanos.

E, para garantir o cumprimento das determinações dos tratados, é usual que aquele Estado, que se obriga internacionalmente, possa ser submetido ao exame dos seus

violado a Convenção Americana de Direitos Humanos é a forma mais efetiva para se assegurar e proteger os direitos elencados na referida Convenção. Para essa afirmação, vide: Relatório da Comissão Interamericana de Direitos Humanos n. 61/01 sobre o caso n. 11.771 (caso Samuel Alfonso Catalán Lincoleo versus Chile), parágrafo 49; e Relatório da Comissão Interamericana de Direitos Humanos n. 136/99 sobre o caso n. 10.488 (caso Ellacuria versus El Salvador), parágrafos 198 a 200.

75 O art. 6 (5) do Protocolo n. II de 1977, Adicional às Convenções de Genebra de 1949, conclama as autoridades, ao final de um conflito armado, a concederem a anistia para os combatentes. 
atos internos por parte dos órgãos de supervisão internacionais, a fim de que se apure se há conformidade com as obrigações internacionais daquele Estado em matéria de Direitos Humanos. No continente americano, por exemplo, conta-se com os esforços desenvolvidos pela Comissão Interamericana de Direitos Humanos e pela Corte Interamericana de Direitos Humanos, cujas atuações primordiais têm sido no sentido de constatar as deficiências nas jurisdições domésticas dos Estados-partes da Convenção Americana de Direitos Humanos, tais como: a inoperância de garantias e meios de defesa, a falta de independência do Poder Judiciário etc., enfim, práticas que restringem a proteção adequada às vítimas de violações de Direitos Humanos.

O problema central do Direito Internacional dos Direitos Humanos encontra-se nas fissuras existentes na concepção teórica da interação entre as normas de Direito Internacional e de Direito Interno, ou seja, a adoção das distintas teorias monista ou dualista. ${ }^{76}$ Por isso, a fim de que se alcance a verdadeira eficácia dos Direitos Humanos, nas palavras de Cançado Trindade ${ }^{77}$ já seria

(...) tempo de superar certos ranços do passado, de afastar de vez o hermetismo de certas construções artificiais fictícias. $\mathrm{O}$ formalismo do requisito do conhecimento da norma jurídica, por exemplo, tem sido, por vezes, levado a extremos inaceitáveis, em detrimento dos direitos individuais (...) Não há como reconhecer ou admitir as obrigações convencionais contraídas por um Estado no plano internacional e ao mesmo tempo negar-lhes vigência no plano do Direito Interno.

Um argumento bastante questionável relaciona-se à tese jurisprudencial, que busca elidir a responsabilidade internacional do Estado por descumprimento dos tratados, ao sustentar a paridade entre os tratados (quaisquer que sejam as matérias por eles reguladas, mesmo as relacionadas aos Direitos Humanos) e as leis ordinárias (infraconstitucionais). E admite, como decorrência lógica, que, se esses instrumentos legais equiparam-se uns aos outros hierarquicamente, podem "derrogar-se" ou "revogar-se" pela interpretação do critério cronológico (lex posteriori derogat priori). ${ }^{78}$

\footnotetext{
${ }^{76}$ A questão teórica é, normalmente, definida como um embate entre dualismo e monismo. Essas duas escolas de pensamento apresentam a hipótese de que existe um espaço comum no qual as ordens jurídicas internacional e interna podem atuar de maneira simultânea em relação a um mesmo fato, sendo que o problema que então se coloca é o de saber qual é a ordem jurídica que deve prevalecer e ser aplicada. Ver: BROWNLIE, Ian. Princípios de direito internacional público. Lisboa: Fundação Calouste Gulbenkian, 1997. p. 44.

77 TRINDADE, Antonio Augusto Cançado. Tratado de direito internacional dos direitos humanos. Porto Alegre: Sergio Antonio Fabris Editor, 1997. v. 1, p. 437.

${ }^{78}$ Nas palavras de Ariosi: "Tem se questionado, exatamente, acerca dessa contribuição de poder ao Judiciário brasileiro que, no momento em que julga estar um tratado internacional revogando lei federal ou sendo revogado por ela, expõe sua conduta de ordem interna para o cenário internacional, interferindo nas relações diplomáticas, de forma generalizada". Ver: ARIOSI, Mariângela. Conflitos entre tratados internacionais e leis internas. O Judiciário Brasileiro e a nova ordem internacional. Rio de Janeiro: Renovar, 2000. p. 188.
} 
Mais recentemente, no Direito brasileiro buscou-se refutar esse entedimento, relacionado ao critério cronológico, por meio da Emenda Constitucional n. 45/04, que acrescentou ao art. 5 da Constituição Federal o $\S 3$, o qual concede um caráter especial aos tratados de Direitos Humanos, conferindo-lhes o status de emenda constitucional, quando aprovados por cada Casa do Congresso, em dois turnos, por três quintos dos votos dos respectivos membros.

Porém, a inserção do referido $§ 3$ acabou por gerar novas polêmicas quanto à vigência dos tratados de Direitos Humanos anteriores, os quais o Brasil vem sistematicamente ratificando ao longo dos anos, pois criou-se a dúvida se: (i) esses tratados, os quais já haviam passado anteriormente por processos de incorporação, deveriam ser novamente revistos e aprovados pelas duas Casas do Congresso, a fim de que a eles fosse concedido o caráter de emenda constitucional, ou (ii) se os tratados que versam sobre Direitos Humanos, que foram recepcionados pelo ordenamento jurídico brasileiro anteriormente à Emenda Constitucional n. 45/04, já possuem hierarquia constitucional por força do art. 5, § 2, da CF-88, dispensando, assim, a implementação do processo legislativo para aprovação de emendas constitucionais.

De toda forma, o que aqui se busca demonstrar é que no campo do Direito Internacional dos Direitos Humanos, a interpretação sobre a paridade normativa entre tratados e leis ordinárias, que aplica o critério cronológico para a solução no que tange às incompatibilidades, é insustentável, pois os tratados de Direitos Humanos, em contraposição aos tratados clássicos, cujo propósito é o de convencionar os interesses recíprocos das partes, consolidam valores comuns superiores com o objetivo final de proteger o ser humano. Por essa razão, requerem interpretação e aplicação distintas e próprias. $^{79}$

A princípio, é possível visualizar três distintos impactos que um tratado de Direitos Humanos pode causar no ordenamento jurídico brasileiro, ou seja, a norma sobre Direitos Humanos elaborada no plano internacional poderá: (a) ser similar à regra já prevista internamente; (b) funcionar como complemento e expandir o rol de direitos

\footnotetext{
${ }^{79}$ Cançado Trindade confirma esse entendimento ao mencionar que: "Há (...) que se ter sempre presente o caráter especial dos tratados de Direitos Humanos, que requerem precisamente a adequação do ordenamento jurídico interno às disposições convencionais de proteção. Segundo este entendimento, a primazia de um tratado do gênero resulta de sua própria natureza jurídica, ao que se agrega o imperativo ético e a necessidade de que o Poder Legislativo (assim como o Judiciário) assegure a consistência entre as leis nacionais e o Direito Internacional. Urge que se desenvolva esta nova visão da matéria, e se promova uma maior aproximação entre os pensamentos constitucionalista e internacionalista, de modo a assegurar uma aplicação mais eficaz dos tratados de Direitos Humanos no âmbito do direito interno". Ver: TRINDADE, Antonio Augusto Cançado. Tratado de direito internacional dos direitos humanos. Porto Alegre: Sergio Antonio Fabris Editor, 1997. v. 1, p. 441.
} 
constitucionalmente estabelecidos; ou (c) ser conflitante com disposição de Direito nacional.

Interessa, primordialmente, ao presente artigo verificar a terceira hipótese acima listada, isto é, aquela que representa a existência de conflito entre uma disposição interna - a lei de anistia - e determinados tratados internacionais de proteção dos Direitos Humanos; pois o impacto dos tratados de Direitos Humanos na ordem interna dos Estados tem chamado atenção nos últimos anos, e têm se destacado os casos em que foram feitas alterações nas respectivas legislações domésticas, com o propósito de harmonizá-las com os dispositivos dos tratados, como a revogação das leis de anistia na Argentina. ${ }^{80}$

Ao se analisar os efeitos desses tratados no Direito Interno, é possível classificar os Estados em dois grandes grupos: os que concedem eficácia direta aos dispositivos dos tratados (nos quais as normas dos tratados são entendidas como selfexecuting ou de aplicabilidade direta), e os Estados cujo ordenamento prevê que, mesmo ratificados, tais tratados não se tornam automaticamente direito interno, para o qual se requer a emissão de legislação específica.

Se essa questão for aplicada ao presente objeto de estudo - a lei de anistia diante do Direito Internacional, uma forma de análise será a solução com base na cronologia, por exemplo, em que a lei de anistia foi emitida e os distintos momentos em que o Brasil obrigou-se internacionalmente diante de tratados que versam sobre Direitos Humanos, conforme será explorado a seguir.

Se fosse aplicado somente o critério cronológico e se o caso fosse de paridade hierárquica entre lei interna e diposição internacional (o que já ficou comprovado não ser mais o enquadramento desde a EC n. 45/04), seguindo o pressuposto de que a lei posterior revoga a lei anterior, deveria prevalecer o direito a um julgamento justo (art. 8) e o direito à proteção judicial (art. 25) previstos na Convenção Americana de Direitos Humanos que foi ratificada pelo Brasil em 1992, por meio do Decreto de promulgação n. 678, de 6 de novembro de 1992, em detrimento da Lei n. 6.683, de 28 de agosto de 1979 (Lei de Anistia), que impede a persecução criminal pelas violações dos Direitos Humanos ocorridas no período compreendido entre 2 de setembro de 1961 e 15 de agosto de 1979.

\footnotetext{
${ }^{80}$ De acordo com a sentença prolatada pela Suprema Corte Argentina, em 14 de junho de 2005: los Estados Partes en la Convención que adopten leyes que tengan este efecto, como lo son las leyes de autoamnistía, incurren en una violación de los artículos 8 y 25 en concordancia con los artículos 1.1 y 2 de la Convención. Las leyes de amnistía conducen a la indefensión de las víctimas y a la perpetuación de la impunidad, por lo que son manifiestamente incompatibles con la letra y el espíritu de la Convención Americana. Consiguientemente, ante la manifiesta incompatibilidad entre las leyes de autoamnistía y la Convención Americana sobre Derechos Humanos las mencionadas leyes carecen de efectos jurídicos y no pueden seguir representando un obstáculo para la investigación de los hechos que constituyen este caso ni para la identificación y el castigo de los responsables. Disponível em: <http://www.derechos.org/nizkor/arg/doc/nulidad.html>. Acesso em: 12 set. 2005.
} 
Essa argumentação recebe ainda mais força, se for considerado que se está diante de duas normas conflitantes de distinta hierarquia legal (emenda constitucional versus lei ordinária federal), de acordo com a estipulação conjunta dos $\S \S \S 1,2$ e 3 do art. 5 da Constituição Federal de 1988, pelo fato de a Convenção Americana de Direitos Humanos possuir status constitucional, ${ }^{81}$ há que se dar prevalência as suas disposições (arts. 8 e 25) revogando-se a lei ordinária que lhe é contrária.

Ainda assim, o Direito Internacional dos Direitos Humanos propõe uma solução por meio da adoção de um critério diferenciado para esse caso especial de conflito hierárquico, porque o tema relaciona-se à garantia dos direitos fundamentais. E esse critério é pautado na escolha da norma mais favorável à vítima, ou seja, em cada dado momento histórico deve prevalecer a norma mais benéfica ao indivíduo, titular do direito que viria a ser atingido ou negligenciado caso outra fosse a resposta para o caso concreto.

A proposta da primazia da norma mais favorável à vítima aqui defendida é a de que, no plano de proteção dos Direitos Humanos, quando houver a interação conflituosa entre o Direito Internacional e o Direito Interno, a solução a ser adotada a fim de pacificar o conflito deve ser a permanência da norma que melhor proteja o ser humano, de tal forma que a primazia seja conferida à pessoa humana.

$\mathrm{O}$ critério da primazia da norma mais favorável às pessoas protegidas tem como aspecto favorável a redução considerável de eventuais possibilidades de conflito entre instrumentos legais, tanto no âmbito vertical, ou seja, conflito entre os tratados e atos de Direito Interno, quanto horizontal, quando se observa a tensão entre dois ou mais tratados. $^{82}$

Esta é a solução apontada por Antônio Augusto Cançado Trindade: ${ }^{83}$

(...) desvencilhamo-nos das amarras da velha e ociosa polêmica entre monistas e dualistas; neste campo da proteção, não se trata da primazia do Direito Internacional ou

\footnotetext{
${ }^{81}$ Ainda que, nesse caso, a Convenção Americana de Direitos Humanos tenha sido ratificada pelo Brasil, em 1992, anteriormente ao entendimento hoje vigente por ocasião da EC n. 45/04, que inseriu o § 3 no art. 5 da Constituição Federal, partilha-se da opinião de que quando se trata de tratados de Direitos Humanos ratificados antes da referida emenda constitucional, consoante o art. 5, §§ 1 e 2 da Constituição Brasileira de 1988, esses passam a integrar o elenco dos direitos constitucionalmente consagrados e direta e imediatamente exigíveis no plano do ordenamento jurídico interno. Vide: PIOVESAN, Flávia. A incorporação, a hierarquia e o impacto dos tratados internacionais de proteção dos Direitos Humanos no direito Brasileiro. In: GOMES, Luiz Flávio; PIOVESAN, Flávia (Orgs.). O sistema interamericano de proteção dos direitos humanos e o direito Brasileiro. São Paulo: Revista dos Tribunais, 2000 e TRINDADE, Antonio Augusto Cançado. Tratado de direito internacional dos direitos humanos. Porto Alegre: Sergio Antonio Fabris Editor, 1997. v. 1, p. 408.

82 TRINDADE, Antônio Augusto Cançado. A interação entre o direito internacional e o direito interno na proteção dos direitos humanos. Arquivos do Ministério da Justiça, v. 46, n. 182, p. 27-54, 1993.

83 TRINDADE, Antônio Augusto Cançado. A proteção dos direitos humanos nos planos nacional e internacional: perspectivas brasileiras. San José da Costa Rica: Instituto Interamericano de Derechos Humanos, 1992. p. 317-318.
} 
do direito interno, aqui em constante interação: a primazia é, no presente domínio, da norma que melhor proteja, em cada caso, os direitos consagrados da pessoa humana, seja ela uma norma de Direito Internacional ou de Direito Interno.

Essa posição também é a adotada por Silvia Steiner ${ }^{84}$ que afirma:

É ainda princípio do Direito Internacional dos Direitos Humanos que eventuais conflitos entre normas de proteção e garantia das pessoas devem se resolver sempre pela norma que mais proteja a vítima da lesão, ou seja, a norma mais benéfica. (...) tratando-se de direitos fundamentais, vige toda sua plenitude o princípio pro hominis, traduzido nas disposições dos arts. 5, § 2, do Pacto de Direitos Civis e Políticos, ${ }^{85}$ e $29, b$ e $d$, da Convenção Americana. ${ }^{86}$

A presente solução, que requer uma interpretação sobre a garantia que se pretende conferir à pessoa humana, afasta, portanto, a aplicação pura e simples da regra da paridade hierárquica, que tem como conseqüência o princípio de que regra posterior derroga regra anterior, o qual era o fundamento jurisprudencial até a alteração proposta pela EC n. 45/04.

A regra da primazia da norma mais protetora é reforçada, por exemplo, pelo art. 29 da Convenção Americana de Direitos Humanos ${ }^{87}$ que, ao apresentar regras sobre as interpretações do tratado, define que nenhuma disposição pode ser interpretada com o propósito de limitar o gozo e o exercício de qualquer direito ou liberdade que possam ser reconhecidos em virtude de leis de qualquer Estado-parte ou em virtude de Convenções em que seja parte um dos referidos Estados.

${ }^{84}$ STEINER, Sylvia Helena de Figueiredo. A convenção americana sobre direitos humanos e sua integração ao processo penal brasileiro. São Paulo: Revista dos Tribunais, 2000.

${ }^{85}$ Dispõe o art. 5, §2, do Pacto de Direitos Civis e Políticos: "Não se admitirá qualquer restrição ou suspensão dos Direitos Humanos fundamentais reconhecidos ou vigentes em qualquer Estado-Parte do presente Pacto em virtude de leis, convenções, regulamentos ou costumes, sob o pretexto de que o presente Pacto não os reconheça ou os reconheça em menor grau". O Brasil ratificou o Pacto de Direitos Civis e Políticos, tendo sido promulgado pelo Decreto n. 592, de 06 de dezembro de 1992. Ver: RANGEL, Vicente Marotta. Direito e relações internacionais. 7. ed. São Paulo: Revista dos Tribunais, 2002. p. 693.

${ }^{86}$ Também André de Carvalho Ramos já se pronunciou nesse sentido: “(...) deve ficar claro que é o Direito Internacional quem determina a prevalência da norma, que, no caso da proteção de Direitos Humanos, é a norma mais favorável ao indivíduo". Ver: RAMOS, André de Carvalho. Responsabilidade internacional por violação de direitos humanos. Rio de Janeiro: Renovar, 2004. p. 149.

${ }^{87}$ A Convenção Americana, em seu art. 29, $b$ e $d$, estabelece que nenhuma disposição da Convenção pode ser interpretada no sentido de: “(b) limitar o gozo e exercício de qualquer direito ou liberdade que possam ser reconhecidos de acordo com as leis de qualquer dos Estados-Partes ou de acordo com outra convenção em que seja parte um dos referidos Estados; (...) (d) excluir ou limitar o efeito que possam produzir a Declaração Americana dos Direitos e Deveres do Homem e outros atos internacionais da mesma natureza". Ver: RANGEL, Vicente Marotta. op. cit., p. 729. 
Pelo disposto no art. 29 da Convenção Americana de Direitos Humanos, entende-se que a primazia é sempre da norma mais benéfica aos Direitos Humanos, seja ela oriunda do Direito Interno ou do Direito Internacional. Sendo afastados, assim, os princípios interpretativos tradicionais que foram elencados acima, como o princípio da norma posterior que revoga a anterior com ela incompatível, ou o princípio da norma especial que revoga a geral no que apresenta de especial. De tal forma que a interpretação a ser utilizada na área do Direito Internacional dos Direitos Humanos será aquela que conduza inevitavelmente à prevalência da norma que melhor e mais eficazmente proteja a dignidade humana.

A adoção do princípio da norma mais benéfica ao indivíduo não encerra, porém, o presente debate, pois, em caso de conflito, essa escolha tradicionalmente caberá aos tribunais nacionais, fato que no cotidiano irá requerer uma exata compreensão quanto à decisão de qual norma melhor assegura a proteção do ser humano.

Mas, para efeito de análise, no presente caso concreto sobre a Lei de Anistia brasileira, poder-se-ia interpretar que provisões estabelecidas pela Convenção Americana, que têm hierarquia constitucional, como o art. 4 (direito à vida); (ii) o art. 5 (direito a um tratamento humano); (iii) o art. 8 (direito a um julgamento justo); (iv) o art. 25 (direito à proteção judicial); (v) o art. 13 (direito à liberdade de pensamento e expressão) representam garantias às vítimas que sofreram violações dos Direitos Humanos em períodos ditatoriais, as quais têm primazia diante da concessão de anistias para as violações dos Direitos Humanos; sendo capaz, portanto, de ultrapassar a aplicação da norma interna que prevê a imunidade.

São Paulo, agosto de 2008.

Referências

AGAMBEN, Giorgio. Estado de exceção. São Paulo: Boitempo, 2004.

ARENDT, Hannah. Responsabilidade e julgamento. São Paulo: Companhia das Letras, 2004.

ARIOSI, Mariângela. Conflitos entre tratados internacionais e leis internas. O Judiciário Brasileiro e a nova ordem internacional. Rio de Janeiro: Renovar, 2000.

BATISTA, Nilo. Aspectos jurídico-penais da anistia. Revista Encontros com a Civilização Brasileira, v. 19, p. 195-206, 1980.

BARROS, Alexandre. Problemas de transição democrática na frente militar: a definição do papel dos militares, a mudança da doutrina e a modernização do país. Política e Estratégia, v. 6, n. 2, p. 206-214, 1988. 
BICUDO, Hélio. Lei de anistia e crimes conexos. Folha de São Paulo, 6 de dezembro de 1995. Caderno Tendências e Debates, p. 1-3.

BROWNLIE, Ian. Princípios de direito internacional público. Lisboa: Fundação Calouste Gulbenkian, 1997.

BOUZAT, Pierre. Traité théorique et pratique de droit penal. Paris: Dalloz, 1951.

BURKE-WHITE, William W. Reframing impunity: applying liberal international law theory to an analysis of amnesty legislation. Harvard International Law Journal, v. 42, n. 2, p. 467-533, 2001.

CABRILLAC, Rémy; FRISON-ROCHE, Marie-Anne; REVET, Thierry (Orgs.). Libertés et droits fondamentaux. 12. ed. Paris: Dalloz, 2006.

CARVALHO FILHO, Aloysio. Comentários ao código penal. Rio de Janeiro: Forense, 1958. v. 4.

CASSESE, Antonio. International criminal law. New York: Oxford University Press, 2003.

COMPARATO, Fábio Konder. Que fizeste de teu irmão? Folha de São Paulo, 13 de agosto de 1995. Caderno Tendências e Debates, p. 1-3.

COMPARATO, Fábio Konder. Questão de decência. Folha de São Paulo, 10 de setembro de 1995. Caderno Tendências e Debates, p. 1-3.

CRAWFORD, James. The international law comission's articles on State responsibility. Introduction, text and commentaries. 3. ed. Cambridge: Cambridge University Press, 2005.

FAUSTO, Boris. A revolução de 1930. In: MOTA, Carlos Guilherme (Org.). Brasil em perspectiva; São Paulo: Difel, 1981.

GASPARI, Elio. A ditadura envergonhada. São Paulo: Companhia das Letras, 2002.

GASPARI, Elio. A ditadura escancarada. São Paulo: Companhia das Letras, 2002.

GOLDMAN, Robert. Amnesty laws and international law: a specific case. In: INTERNATIONAL Comission of Jurists. Seminar on Justice Not Impunity. Geneva: ICJ, 1992.

HADDEN, Tom; HARVEY, Colin. The law of internal crisis and conflict. International Review of the Red Cross, v. 833, p. 119-133, 1999.

HÉLIE, Faustin. Pratique criminelle des cours et tribunaux. 5. ed. Paris: Marchal Billard, 1887.

MAGGIORE, Giuseppe. Derecho penal. Bogotá: Temis, 1972.

MAGNOL, Vidal. Cours de droit criminel et de science pénitentiaire. 8. ed. Paris: Rosseau, 1935.

RANGEL, Vicente Marotta. Direito e relações internacionais. 7. ed. São Paulo: Revista dos Tribunais, 2002.

MELLO, Celso D. de Albuquerque. Direitos humanos e conflitos armados. Rio de Janeiro: Renovar, 1997. 
MERA, Jorge. Chile: truth and justice under the democratic government. In: ARRIAZA, Naomi Roth (Org.). Impunity and human rights in international law and practice. New York: Oxford University Press, 1995. p. 171-184.

MEZAROBBA, Glenda. Um acerto de contas com o futuro:- a anistia e suas conseqüencias - um estudo do caso brasileiro. 2003. Dissertação (Mestrado) - Faculdade de Filosofia, Letras e Ciências Humanas; Universidade de São Paulo, São Paulo.

MOMTAZ, Djamchid. The minimum humanitarian rules aplicable in periods of internal tension and strife". International Review of the Red Cross, v. 324, p. 455-462, 1998.

PIOVESAN, Flávia. A incorporação, a hierarquia e o impacto dos tratados internacionais de proteção dos direitos humanos no direito Brasileiro. In: GOMES, Luiz Flávio; PIOVESAN, Flávia (Orgs.). O sistema interamericano de proteção dos direitos humanos e o direito Brasileiro. São Paulo: Revista dos Tribunais, 2000.

RAMOS, André de Carvalho. Responsabilidade internacional por violação de direitos humanos. Rio de Janeiro: Renovar, 2004.

ROUQUIÉ, Alain. O estado militar na América Latina. São Paulo: Alfa-Omega, 1984.

SANTOS, Boaventura de Souza. Os crimes políticos e a pena de morte.Revista de Direito Penal, v. $1,1971$.

SLYE, Ronald C. The legitimacy of amnesties under international law and general principles of anglo-american law: is a legitimate amnesty possible? Virginia Journal of International Law, v. 43, n. 1,2002 .

STEINER, Sylvia Helena de Figueiredo. A convenção americana sobre direitos humanos e sua integração ao processo penal brasileiro. São Paulo: Revista dos Tribunais, 2000.

STOPPINO, Mário. Ditadura. In: BOBBIO, Norberto; MATTEUCCI, Nicola; PASQUINO, Gianfranco (Orgs.). Dicionário de política. 3. ed. Brasília: UnB, 1991.

TRINDADE, Antonio Augusto Cançado. Tratado de direito internacional dos direitos humanos. Porto Alegre: Sergio Antonio Fabris Editor, 1997. v. 1.

TRINDADE, Antônio Augusto Cançado. A interação entre o direito internacional e o direito interno na proteção dos direitos humanos. Arquivos do Ministério da Justiça, v. 46, n. 182, p. 27-54, 1993.

TRINDADE, Antônio Augusto Cançado. A proteção dos direitos humanos nos planos nacional e internacional: perspectivas brasileiras. San José da Costa Rica: Instituto Interamericano de Derechos Humanos, 1992. p. 317-318.

VIZENTINI, Paulo Gilberto Fagundes. A experiência histórica do Brasil e da Argentina contemporâneos: autoritarismo e desenvolvimento (1964-1985). LLADÓS, José Maria; GUIMARÃES, Samuel Pinheiro (Orgs.). Perspectivas: Brasil e Argentina. Brasília: IPRI, 2000. 